\title{
Transformasi Loyalitas Primordial sebagai Basis Identifikasi Kepartaian: Kasus Partai Kebangkitan Bangsa dalam Pemilihan Umum 1999 dan 2004
}

\author{
Karim Suryadi
}

ABSTRACT

\begin{abstract}
Transformation of primordial loyalty into the political sphere rather than understanding of the substance of the party's platform is a key factor for PKB's (National Awakening Party) devotees to adhere to the party. The platform has not been effectively socialized. The practice of the party has not been believed as a requisite condition to create an order society. On the other hand, adhering to Nahdlatul Ulama (NU) and inclining to submit to orders or wishes of Kiai (Muslim Scholars) is believed among PKB's voters as a means by which a good community is created (khoerul barriyah). Therefore, since the 2004 General Election,

Kiai's political communication and orientations have become the partisans' primary roles among $P K B$ 's constituents.
\end{abstract}

Kata kunci: "platform", identitas partai, komunikasi politik kiai, partisan, loyalitas primordial

\section{Pendahuluan}

Kemunculan Partai Kebangkitan Bangsa (PKB) dalam pusaran arus politik partai pasca Orde Baru menarik dikaji karena dua alasan berikut. Pertama, keterlibatan Pengurus Besar Nahdlatul Ulama (PBNU) dalam membidani kelahiran PKB mengisyaratkan keseriusannya dalam mengarahkan suara warga Nahdlatul Ulama (NU). Lebih dari sekadar merestui, keterlibatan PBNU dapat dibaca sebagai kesungguhan dalam melahirkan sang "putra mahkota". Padahal, aspirasi politik nahdliyin tidak benar-benar monolit. Partai politik yang lahir dari rahim NU bukan hanya PKB. Hal ini memunculkan dugaan adanya kesadaran yang mempersatukan dan mendesak warga NU untuk sementara - hanya akan berkhidmat pada PKB.
Kedua, dibanding partai baru lainnya, $\mathrm{PKB}$ adalah peraih suara terbanyak pada Pemilu 1999. Perolehan suara PKB mendekati raihan suara Partai NU pada Pemilu 1955. Jumlah ini melampaui raihan suara Partai Persatuan Pembangunan (PPP), yang sudah hadir sejak Orde Baru dan merupakan hasil fusi NU dengan Partai Muslimin Indonesia (Parmusi), Partai Syarikat Islam Indonesia (PSII), dan Persatuan Tarbiyah Indonesia (Perti), pada 5 Januari 1973.

Kembalinya NU ke kancah politik menarik dikaji, karena sejak 1984 NU memutuskan kembali ke khittah 1926. Keputusan ini bukan hanya mengharuskan NU menanggalkan atribut partai, tetapi juga menegaskan kembali jati dirinya sebagai organisasi sosial keagamaan (jam'iyyah diniyah). Fenomena ini memunculkan pertanyaan, faktor apa 
yang membuat dukungan terhadap PKB yang dianggap sebagai "titisan" Partai NU ini relatif stabil, padahal deideologisasi yang dijalankan Orde Baru berlangsung sangat intensif?

\section{Metode Penelitian}

Kemunculan PKB sebagai pemenang ketiga di bawah Partai Demokrasi Indonesia Perjuangan (PDIP) dan Partai Golongan Karya (Golkar), atau terbesar dibandingkan seluruh partai yang muncul pasca-Orde Baru, mengisyaratkan adanya gejala "reinkarnasi" politik NU yang tidak sempurna. Dugaan ini muncul karena kelahiran PKB dibidani NU, sehingga PKB menjadi anak emas NU. Namun, perolehan suara PKB yang jauh di bawah jumlah pemilih yang diasumsikan berhaluan NU menyiratkan dukungan warga NU terhadap PKB tidak bulat.

Selain menguatnya isu primordial, kemunculan partai politik menjelang Pemilu 1999 ditandai absennya platform yang dapat menggugah partisipasi publik. Fenomena ini memunculkan dugaan bahwa keputusan yang diambil pemilih saat memberikan suara dan loyalitas yang terbangun di kalangan para anggota lebih didasarkan atas pertimbangan di luar pemahaman mereka tentang platform partai.

Penelitian ini menggunakan metode studi kasus sebagai salah satu tradisi kualitatif(Creswell, 1998: 63) dengan pendekatan proses (Combs, 1981: 39-66). Proses sosialisasi platform pluralitas Partai Kebangkitan Bangsa (PKB) dan komunikasi politik kiai dalam membentuk identifikasi kepartaian dijadikan kasus dalam penelitian ini.

Data primer dalam penelitian ini dikumpulkan melalui wawancara terhadap 16 informan kunci dan beberapa kelompok informan yang digali dalam bentuk diskusi (focus group discussion). Untuk menghindari "bias partai", informasi dikumpulkan pula dari politisi NU yang berkiprah di luar PKB, seperti di PPP, Golkar, Partai Bintang Reformasi, dan PAN.

Informan ditentukan secara snowball, sehingga lokasi penelitian bergantung kepada di mana informan berada atau peristiwa politik yang digelar PKB berlangsung. Bandung, Jakarta, Cirebon, Sukabumi, Sampang, Pasuruan, dan Surabaya, sebagai daerah yang dikenal sebagai basis PKB menjadi daerah penelitian yang utama, serta Nusa Tenggara Timur (NTT), sebagai daerah percontohan pengembangan wawasan kebangsaan ala PKB.

Selain digali melalui wawancara mendalam, data primer dihimpun melalui pengamatan terlibat terhadap sejumlah objek dan peristiwa. Untuk kepentingan penelitian ini, telah dilakukan pengamatan dan wawancara dengan para pelaku yang terlibat dalam perumusan calon anggota legislatif dan kampanye menjelang Pemilu 2004. Berbagai forum yang bertujuan mematangkan calon presiden yang akan dimajukan PKB dan kampanye pemilihan presiden menjadi peristiwa yang penting.

Sementara, data sekunder dihimpun dari informasi kepustakaan, baik dari buku teks, jurnal ilmiah, hasil penelitian, laporan, dan dokumen; baik yang diterbitkan untuk umum maupun dokumen yang diterbitkan untuk kalangan internal PKB. Keseluruhan hasil penelitian kepustakaan menjadi sumber data yang penting bagi penelusuran polapola partisipasi dan komunikasi politik NU. Penelusuran data dokumenter difokuskan kepada keterlibatan ulama/kiai dalam wilayah politik serta akar-akar tradisi yang menjadi rujukan penyusunan platform.

Keseluruhan data dihimpun mulai September 2003 hingga Juni 2005. Data final yang dianalisis dan disajikan adalah data yang telah diseleksi melalui member checking.

\section{Genesis "Platform" dan Filogeni Politik PKB}

Bila dilihat dari kulturnya, PKB bukan entitas yang benar-benar baru. PKB hanya mewadahi sesuatu yang sudah ada, yakni komunitas NU dengan segenap sistem nilai yang dianutnya. Meskipun tidak terdapat hubungan organisatoris antara NU dan PKB, namun di antara keduanya sulit dipisahkan. PKB memang bukan organisasi yang dibentuk dengan tugas melaksanakan pro- 
gram-program NU, namun secara embrional PKB dan NU dihubungkan oleh "plasenta" yang sulit diputus.

Keterlibatan PBNU dalam membidani kelahiran PKB sampai pada derajat dituduh melanggar Khittah 1926, mengimplikasikan hal-hal berikut. Pertama, hasrat politik NU tidak padam karena langkah penarikan diri dari wilayah politik praktis. Hasrat berpolitik warga nahdliyin pun tidak tergerus deideologisasi yang diterapkan rezim Orde Baru. Bahkan langkah ini terbukti menjadi titik tolak ploriferasi politik NU.

Kedua, keputusan NU memfasilitasi pembentukan PKB merupakan bentuk adaptabilitas sikap politik NU. Fleksibilitas sikap politik NU terlihat di sepanjang sejarah pertumbuhan NU. Baik sebagai organisasi kemasyarakatan (jam'iyyah diniyah) maupun sebagai partai politik, sikap politik NU terkenal lentur. Meskipun dalam kasus tertentu NU tampil radikal (seperti menolak Perjanjian "Linggarjati" dan "Renville" atau ketika menolak Mutual Secutity Act dan dewan keamanan bersama yang pro AS pada 1952), namun watak akomodatif lebih mewarnai sikap politik NU.

Keterbukaan yang digagas para pendiri PKB dilandasi pandangan bahwa corak partai politik masa depan adalah lintas etnis, jauh melampaui keanggotaan sebuah organisasi kemasyarakatan. Pandangan ini menempatkan Pancasila sebagai asas partai, sekaligus menempatkan Islam sebagai akhlak masyarakat (etika sosial), dan sumber materi perundangan.

Beberapa dasar pertimbangan menyangkut pemilihan nama partai mengisyaratkan bahwa secara kultur PKB mengadopsi sikap kemasyarakatan yang dikembangkan NU. Kultur PKB adalah kultur NU, karena PKB adalah pengorganisasian kultur NU secara politik. Kultur Islam ahlussunnah wal Jama'ah menjadi basis historis dan ideologis PKB, yang bersenyawa dengan sejarah perjalanan kebangsaan dan kenegaraan Indonesia.

Namun, tidak semua warga NU memiliki pandangan yang sejalan dengan para pendiri PKB. Beberapa ulama mengritik karakter PKB yang terlalu berorientasi kebangsaan dan tidak secara tegas meneruskan tradisi politik Partai NU. Hal ini mengisyaratkan bahwa sikap politik warga NU tidak monolit. Mereka memiliki pemahaman yang beragam tentang bagaimana seharusnya tradisi politik NU ditransformasikan ke dalam praksis politik masa kini. Keragaman tadi telah mendorong munculnya beragam partai yang memiliki sejarah kekerabatan dengan NU (filogeni).

Filogeni politik PKB tidak didorong oleh perbedaan ideologis di antara empat partai yang lahir di kalangan NU. Perbedaan tadi hanya memperlihatkan "jalan yang berbeda menuju tujuan yang sama". Selain karena friksi yang terjadi di kalangan elit NU, kemunculan partai tersebut lebih disebabkan perbedaan penafsiran tentang bagaimana seharusnya sistem nilai yang dianut NU ditransformasikan ke dalam wilayah politik. Perbedaan tadi melemahkan barisan politik NU. Kekuatan NU terpecah ke dalam sekutu-sekutu kecil yang mudah digilas kekuatan lain.

Mabda Siyasiy memberikan gambaran jelas tentang hakikat PKB dan garis perjuangannya. Ideologi humanisme religius bukan hanya berakar pada fitrah manusia, tetapi juga mempertimbangkan taraf perkembangan manusia dalam konteks sosial. Paradigma humanisme berakar pada hakikat manusia yang suci, cenderung pada hal-hal yang baik, keunggulan indrawi dan memiliki akal. Sedangkan dimensi religius berkaitan dengan hidayah wahyu, pertolongan, dan petunjuk Allah swt. Artinya, selain menerima nilai-nilai yang diturunkan Allah swt, PKB pun menyerap nilainilai yang tumbuh dari perkembangan manusia.

Mengacu kepada sistem nilai yang terkandung di dalam Mabda Siyasiy jelas bahwa partai yang dikehendaki adalah partai yang terbuka. Meski naskah ini dirumuskan para tokoh NU, namun PKB tidak dimaksudkan sebagai reinkarnasi Partai NU. Berbeda dengan Partai NU yang pada awalnya mencita-citakan terwujudnya syari'at Islam dalam tatanan kenegaraan, PKB tidak mengusung formalisme Islam. Bagi PKB, mengambil sari pati nilai-nilai Islam untuk diangkat ke dalam hukum positiflebih diutamakan daripada menjadikan syari'at Islam sebagai dasar negara.

Kiai menjadi simbol signifikan dalam 
komunikasi politik PKB. Di antara para kiai, Abdurrahman Wahid masih menjadi primus inter pares. Figuritas Gus Dur bukan hanya dibentuk oleh keunggulan dari segi nasab, tetapi juga didukung oleh keluasan pengetahuan, paham pluralitasnya, dan sensitivitas terhadap budaya lokal. Pemerintahan Wahid yang hanya 21 bulan menjadi eksperimen implementasi platform pluralitas PKB.

Demokrasi dan penguatan masyarakat sipil (civil society) menjadi kredo (paham) pemerintahan Abdurrahman Wahid. Hal ini terlihat dari wacana dan langkah-langkah politik yang diambil Abdurrahman Wahid dalam 21 bulan kepemimpinannya.

Ide membangun kemandirian masyarakat sehingga tidak bergantung sepenuhnya kepada negara (otonomi relatif warga negara) menjadi gagasan besar Abdurrahman Wahid. Gagasan tadi diterjemahkan ke dalam wacana (kesatuan tutur) supremasi sipil, kemerdekaan pers dan kebebasan berbicara, pembelaan hak minoritas, penguatan posisi masyarakat di hadapan negara, supremasi hukum, dan deformalisasi Islam.

Selain mengembangkan wacana di atas, Abdurrahman Wahid pun melakukan "ijtihad" dalam hal hubungan penguasa dan rakyatnya. Kepala negara yang sebelumnya "sulit disentuh", dicitrakan sebagai terbuka dan dekat dengan rakyat. Hal ini paling tidak terlihat dari tindakannya melakukan desakralisasi istana dan memajukan informalitas komunikasi politik.

\section{Identifikasi Kepartaian}

Terlepas dari perolehan suara PKB yang masih kecil, langkah-langkah yang ditempuh kader PKB NTT memperlihatkan fenomena menarik. Fenomena tadi dalam beberapa hal mirip langkahlangkah yang ditempuh pengurus PKB di Jawa dengan spektrum yang berbeda.

Pertama, seperti halnya di Jawa, di NTT figur Gus Dur menjadi faktor penentu. Bukan platform yang memikat mereka. Figur Gus Dur yang dinilai mampu memberi keteduhan bagi warga Kristiani menawan mereka.
Kedua, seperti halnya di Jawa, identifikasi kepartaian belum terbentuk. Pemanfaatan struktur keagamaan Kristen sebagai strategi perluasan dukungan mendekati pola rekrutmen di Jawa yang memanfaatkan jaringan pesantren. Dengan kata lain, baik di Jawa maupun di NTT yang terjadi adalah transformasi kesetian primordial ke wilayah politik.

Ketiga, pemanfaatan pranata budaya sebagai media komunikasi politik. Ke dalamnya termasuk melakukan politik kultural dengan memanfaatkan opinion leaders, baik dalam wilayah adat maupun agama. Hal ini dimungkinkan karena masyarakat NTT terstruktur secara hierarkhis dengan raja dan kepala suku sebagai patronnya. Realitas terakhir, lagi-lagi, memiliki kemiripan dengan struktur masyarakat Jawa yang sentris, meski yang menjadi patron bukan kepala suku.

Keempat, selain menarik simpati masyarakat yang terlanjur jatuh hati pada Partai Golkar dan PDIP (orientasi merah-kuning) tantangan yang dihadapi kader PKB NTT adalah pencitraan. Citra PKB sebagai partai Islam melekat cukup kuat di benak masyarakat NTT. Citra seperti ini tidak menunjang pemasaran politik PKB. Karena itu, langkah yang ditempuh adalah mengarusutamakan citra PKB sebagai partai terbuka, nasionalis, dan demokratis. Namun dalam praktiknya, strategi tadi berbentuk deislamisasi, yakni mengurangi simbolsimbol keislaman.

Fenomena terakhir, berbeda kontras dengan realitas PKB di Jawa, khususnya Tapal Kuda. Namun, keduanya menemukan titik temu, yakni isu agama dan primordial menjadi "kartu" yang menentukan. Inilah dilema PKB dalam membangun demokrasi. Membangun demokrasi tidak bisa berlandaskan primordialisme, sebab nalar demokrasi menuntut egalitarianisme, transparansi, dan tanpa diskriminasi dalam semua bidang.

\section{Pola Komunikasi Politik Kiai}

Meskipun PKB bersifat terbuka dan dihuni oleh orang-orang dengan latar belakang budaya yang beragam, namun kultur NU tetap dominan. Dalam berbagai acara yang digelar PKB, baik di 
pusat maupun di daerah, kultur dan simbol NU masih menjadi mainstream (arus utama). Pembacaan shalawat dalam acara-acara yang digelar PKB adalah indikasi penetrasi kultur NU terhadap budaya komunikasi PKB.

Budaya NU menjadi rujukan reproduksi simbol-simbol PKB. Simbol-simbol PKB adalah modifikasi simbol-simbol NU yang ditransformasikan ke dalam lingkungan yang lebih luas. Proses transformatif tadi dapat dilukiskan dalam gambar berikut.

Kiai menjadi nucleus (unsur inti) komunitas pesantren dan NU. Pada gilirannya, ketiga unsur ini menjadi sumber dan rujukan dalam proses reproduksi simbol-simbol PKB. Dengan kata lain, simbol PKB adalah simbol-simbol NU yang telah mengalami metamorfosis. Di dalam proses ini, kiai yang berorientasi politik (political-oriented kiai) menjadi agen yang mempersambungkan prosesproses transformatif tadi.

Introduksi cara-cara modern (modernisasi) yang melanda warga NU - seperti yang ditandai oleh kahadiran struktur modern - belum mengubah pola-pola relasi yang sudah ada. Bahkan, ikatan terhadap faktor-faktor primordial menguat sejalan dengan pelekatan diri mereka terhadap struktur formal yang mereka ciptakan. Fenomena inilah yang menimbulkan kecenderungan munculnya etnisitas dalam politik (political ethnicity).

Modernisasi yang dijalani PKB tidak ditempuh dengan cara mengikis pola hubungan yang sudah ada, melainkan hanya memfungsikan kembali struktur-struktur tradisional yang sudah diwarisi. Faktor nasab, etnis, dan usia, masih menjadi unsur primer dalam alokasi kekuasaan. Diferensiasi antara wilayah politik dan religius hampir tidak terjadi. Hal ini dimungkinkan karena teologi sosial politik yang dianut amat fleksibel dalam menghadapi perubahan-perubahan yang muncul akibat politik modernisasi yang ditempuh PKB.

Sebagai pengorganisasian kultur NU secara politik, PKB mewarisi kerangka berpikir khas NU, yang tidak lain adalah organisasi sosial keagamaan (jam'iyyah ijtima'iyyah diniyyah). Kerangka berpikir tadi tampak dalam ciri-ciri primer NUdan dalam kiprah politiknya. Ciri-ciri primer tadi ditransformasikan ke dalam praksis politik PKB sehingga menjadi basis identifikasi kepartaian, terutama di daerah-daerah yang dikenal basis NU. Namun, sebagai partai politik yang dimaksudkan sebagai alat transformasi sosial politik NU, PKB dituntut memiliki sensitivitas terhadap nilai sosial politik yang relevan dengan kaidah-kaidah yang dianut NU.

Secara normatif, kerangka berpikir tadi ditemukan di dalam dokumen-dokumen historis PKB, tempat di mana ideologi politik PKB dituangkan. Preferensi tentang masyarakat dan negara yang dicita-citakan PKB bukan hanya berbasis pada etika dan nilai-nilai keagamaan, tetapi juga tidak sekuler - dalam arti memisahkan kehidupan bernegara dari kehidupan beragama meski sejak awal PKB tidak menghendaki formalisasi Islam.

Dilihat dari konteks di atas, sifat terbuka yang dianut PKB berkonotasi sebagai quasi terbuka, atau dalam bahasa para kiai di Jawa Timur sebagai "terbuka yang tertutup". Keterbukaan PKB berlaku sampai pada titik tidak mengganggu sistem nilai yang dianut NU. Sederhananya, PKB bersifat tertutup terhadap anasir-anasir yang merusak kaidah dasar yang dianut warga NU.

Dengan kata lain, quasi terbuka bermakna PKB itu inklusif sekaligus ekslusif. Inklusif dalam hal muamalah dan interaksi sosial, tetapi eksklusif dalam hal ibadah dan akidah. Kaidah ini bermakna bahwa PKB dapat menggelar kegiatan muamalah dan interaksi sosial tanpa membedakan agama dan latar belakang sosial budaya. Namun, PKB harus membatasi diri pada hal-hal yang menyangkut ibadah dan akidah.

Dalam hubungannya dengan anasir-anasir agama yang membentuk konfigurasi dukungan bagi PKB, keterbukaan harus dipahami sebagai sikap toleran (tasamuh) terhadap agama mana pun tanpa meninggalkan keyakinan teologisnya sendiri. Di dalam wilayah ibadah dan akidah, PKB tidak memiliki otoritas untuk ikut campur, meski tidak akan pernah terlepas sama sekali.

Karena itu, platform pluralitas PKB menuntut manajemen komunikasi tersendiri dalam proses 
sosialisasinya mengingat fakta bahwa PKB telah secara nyata membuka basis dukungan di kalangan non NU, bahkan non-Islam. Manajemen komunikasi PKB perlu dirancang paling tidak untuk dua kebutuhan.

Pertama, memelihara dukungan pemilih dari kalangan Muslim yang menjadi captive market, sekaligus menarik dukungan non-Muslim lewat penampilan sosok partai yang moderat. Sebelum menarik kelompok kedua, PKB harus mempertahankan dukungan kelompok pertama dengan meyakinkan bahwa format "Islam Kebangsaan" yang dianut NU dan diwarisi PKB adalah salah satu bentuk jawaban dalam mengatasi berbagai persoalan, khususnya dalam masalah relasi agama dan negara.

Sosok partai yang moderat menjadi daya tarik PKB di kalangan non-Muslim, paling tidak di Nusa Tenggara Timur. Beberapa pemilih PKB di kota Kupang mengaku tertarik pada PKB karena mampu memberi kesejukan bagi warga Kristiani, yang dalam kehidupan nasional menjadi minoritas. Sayangnya, eksperimen PKB menarik dukungan non-Muslim tidak dapat meningkatkan raihan suara PKB secara signifikan dalam Pemilu 2004. Bahkan, secara nasional raihan suara PKB menurun bila dibandingkan Pemilu 1999.

Kedua, menggeser kekuatan PKB dari anasiranasir yang bersifat primordial ke arah keunggulan kompetitifyang berlandaskan kultur, program, dan kepemimpinan. Namun, transformasi nilai tadi tidak bisa dilakukan secepat membalikkan telapak tangan karena ia menyangkut atribut sosial yang telah terlanjur dianggap sebagai pandangan hidup (ways of life).

Dikaji dari perspektif tadi, sosialisasi platform pluralitas PKB bertolak dari keyakinan bahwa akidah dan ritus ibadah setiap agama adalah hak ekslusif setiap pemeluknya. Wilayah ini merupakan area privat, yang tidak menjadi otoritas PKB untuk merekayasanya. Sosialisasi platform pluralitas PKB tidak menjangkau wilayah akidah dan ibadah, meskipun senantiasa mendapatkan penetrasi, bahkan dengan sengaja menyerap, nilai agama yang ditransformasikan ke dalam gelanggang politik.
Dengan demikian, medan khidmat sosialisasi platform pluralitas PKB adalah wilayah muamalah dan interaksi sosial, yakni seperangkat panduan sosial yang diturunkan dari nilai-nilai keagamaan dan berlaku universal. Mengacu kepada rumusan platform $\mathrm{PKB}$, nilai-nilai dasar dimaksud mencakup beberapa hal. Kesatu, jaminan penegakan HAM dan kejujuran besumber hati nurani (as-shidqu). Kedua, mengembangkan sikap dapat dipercaya, setia dan tepat janji. Ketiga, menciptakan tatanan masyarakat yang mampu memecahkan masalah sosial (al-amanah wa al-wafau bi al-ahdli), adil (al-'adalah), tolong-menolong (al-ta'awun), konsisten (al-istiqamah), musyawarah (al-syura), dan kesamaan kedudukan di muka hukum (almusawa).

Fakta bahwa tidak semua orang yang mengidentifikasikan dirinya dengan NU memilih PKB menunjukkan bahwa keputusan untuk memilih tidak semata-mata ditentukan oleh kekuatankekuatan dari luar. Demikian pula fakta bahwa sejumlah non-Muslim yang memutuskan memilih PKB menunjukkan bahwa tindakan politik mereka tidak tunduk pada pencitraan yang mengesankan PKB sebagai partai orang Islam. Kedua fakta ini mengisyaratkan bahwa tindakan politik warga PKB melibatkan proses interpretatif atas simbol-simbol yang dipertukarkan ketika proses komunikasi politik berlangsung.

Dikaji dari perspektif interaksi simbolik, sosialisasi platform pluralitas PKB akan bergantung kepada kualitas hubungan dan kelangsungan interaksi, di mana kedua pihak (aktivis, politisi, dan komunikator profesional versus khalayak, simpatisan, dan konstituen PKB) saling menukar makna dan kelakuan. Sebuah transaksi politik yang di dalamnya melibatkan proses penciptaan kesan melalui proses impression management (Goffman, 1959: 203).

Penataan kesan menjadi kunci keberhasilan politisi dalam serangkaian proses transasksi politik, karena sejak lama diyakini bahwa banyak aspek politik berupa penampilan (appearance). Para politikus beraksi di depan publik sedemikian rupa, sehingga mereka menganggapnya sebagai orang penting, pintar, dan layak dipercaya untuk 
mengemban amanah. Para pemimpin dan aktivis partai politik harus memainkan peran seperti yang dibayangkan khalayak. Mereka akan selalu menemukan banyak orang yang siap "dikelabui". Mereka menjanjikan sesuatu, sehingga mereka dikesani sebagai sosok yang merasakan sesuatu serta berpikir dan bertindak menurut apa yang dibayangkan konstituennya.

\section{Kesimpulan}

Pertumbuhan politik kepartaian di Indonesia tidak identik dengan sekularisasi, melainkan transformasi kesadaran religius ke dalam wilayah politik. Keyakinan bahwa urusan politik dapat diatur dan ditentukan oleh kehendak manusia sendiri tidak menafikan hak prerogatif Tuhan dalam keseluruhan proses tersebut.

Komunikasi internal dan esksternal yang tidak efektif menyebabkan substansi platform tidak tersosialisasikan dengan baik. Akibatnya keberadaan platform menjadi tidak fungsional. Platform menjadi atribut yang menunjang penampilan politisi dalam panggung depan. Kedudukan platform tergantikan oleh figur yang menjadi ikon (icon) sekaligus ruh partai. Kondisi ini melahirkan pola komunikasi politik yang melekatkan kredibilitas komunikator pada faktor-faktor yang diwariskan (askriptif) dan menempatkan figur sebagai mesiah. Pola ini mengukuhkan budaya konteks tinggi (high contex) yang ditandai oleh penggunaan kode terbatas (restricted codes). Spektrum komunikasi internal dan eksternal partai yang tidak egaliter bukan hanya menjadikan klaim inklusivitas sebagai keterbukaan semu (quasi terbuka), tetapi juga mempertajam segregasi antarfaksi, sehingga partai menjadi mudah terfragmentasi ke dalam kekuatan sempalan.

Penguasaan sumber daya komunikasi partai politik yang terpusat di tangan figur melahirkan kepemimpinan partai yang mesianik. Pola ini bukan hanya melekatkan otoritas kepemimpinan pada tradisi dan kharisma sebagaimana lazim dianut selama ini, tetapi juga menempatkan figur sebagai mesiah (ratu adil) yang tidak pernah berbuat salah.
Kepemimpinan mesianik dikukuhkan oleh pola orientasi pengikut yang bercorak parokhial dan rekrutmen yang berdasar kepada nasab sehingga kelahiran dan perkawinan menjadi alat promosi karier yang penting. Sedemikian pentingnya peran politik keluarga-penguasa, maka perhatian para pencari kekuasaan tertuju pada pola kekuasaan keluarga sebagai miniatur pola kekuasaan partai. Partai sulit memainkan perannya sebagai representasi kepentingan pengikut, melainkan hanya mengukuhkan dominasi kaukus yang dibentuk tokoh-tokoh senior partai (gerontocracy). Kecenderungan ini mengukuhkan keberlakuan hukum besi oligarkhi, dimana aristokrat tradisional berperan sebagai oligoi-oligoi yang mengendalikan partai.

Pola komunikasi politik yang askriptif dan kepemimpinan mesianik menyebabkan tidak terbangunnya wacana kritis di kalangan fungsionaris dan simpatisan partai. Identifikasi kepartaian tidak terbangun atas penguasaan nilai dasar dan cita-cita partai, melainkan merupakan bentuk transformasi kesetiaan primordial ke dalam praksis politik. Involusi politik ini dikukuhkan oleh pola sosialisasi yang menempatkan kepatuhan di atas pertimbangan rasional. Manipulasi simbolsimbol agama dan budaya menjadi unsur primer dalam komunikasi antara pemimpin dengan pengikut sekaligus menjadi alat dominasi dan mobilisasi dukungan yang penting. Pola komunikasi tadi ditandai oleh pemakaian alat-alat retorika (baik verbal maupun nonverbal) yang bersumber dari - atau adaptasi bentuk ritual - agama dan budaya sehingga pemaknaan atas simbolsimbol tersebut bersifat isoterik sesuai dengan pengalaman religio-politik penggunanya.

Proses tersebut bukan hanya memberi peluang terjadinya kesalahpahaman, tetapi juga menguatkan kecenderungan menjadikan agama dan budaya sebagai alat justifikasi keputusan dan tindakan politik. Prinsip "ekonomi pernyataan" bukan hanya dapat mengurangi risiko keterpurukan citra akibat kesalahan manajemen komunikasi, tetapi juga dapat menambah daya persuasi komunikasi politik. 


\section{Daftar Pustaka}

Alwasilah, A. Chaedar. 2002. Pokoknya Kualitatif: Dasar-dasar Merancang dan Melakukan Penelitian Kualitatif. Jakarta: Pustaka Jaya.

Combs, James E \& Dan Nimmo 1981. A Primer of Politics. New York: Macmillan Publishing Company.

Creswell, John W. 1994. Research Design: Qualitative \& Quantitative Approaches. California: SAGE Publications.

1998. Qualitative Inquiry and Research Design: Choosing Among Five Traditions. California: SAGE Publications.

Feith, Herbert. 1962. The Decline of Constitutional Democracy in Indonesia. New York: Cornell University Press.

Feith, Herbert \& Lance Castles. 1970. Indonesian Political Thinking 1945-1965. USA: Cornell University.

Geertz, Clifford. 1981. Abangan, Santri, Priyayi dalam Masyarakat Jawa. Jakarta: Pustaka Jaya.

1992. Kebudayaan \& Agama, terjemahan Francisco Budi Hardiman. Yogyakarta: Kanisius.
1963. Old Societies and New States: The Quest for Modernity in Asia and Africa, The Free Press of Glencoe.

Goffman, Erving. 1974. The Presentation of Self ini Everyday Life. USA: Penguin Books.

Lewellen, Ted C. 1982. Political Anthropology, Berger L. Carey Publisher.

Martindale, Don. 1960. The Nature and Types of Sociological Theory, Cambridge, Massachusetts, The Riverside Press.

Mulyana, Deddy. 2001. Metode Penelitian Kualitatif: Paradigma Baru Ilmu Komunikasi dan Ilmu Sosial Lainnya. Bandung: Remaja Rosdakarya.

Nimmo, Dan D. dan Keith R. Sanders. 1981. Handbook of Political Communication. California: Sage Publication, Inc.

1978. Political Communication and Public Opinion in America. California: Goodyear Publishing Company.

Sherman, Arnolk K, dan Aliza Kolker. 1987. The Social Bases of Politics. Belmont: Wardworth Publishing Company, 


\title{
Transformasi Loyalitas Primordial sebagai Basis Identifikasi Kepartaian: Kasus Partai Kebangkitan Bangsa dalam Pemilihan Umum 1999 dan 2004
}

\author{
Karim Suryadi
}

ABSTRACT

\begin{abstract}
Transformation of primordial loyalty into the political sphere rather than understanding of the substance of the party's platform is a key factor for PKB's (National Awakening Party) devotees to adhere to the party. The platform has not been effectively socialized. The practice of the party has not been believed as a requisite condition to create an order society. On the other hand, adhering to Nahdlatul Ulama (NU) and inclining to submit to orders or wishes of Kiai (Muslim Scholars) is believed among PKB's voters as a means by which a good community is created (khoerul barriyah). Therefore, since the 2004 General Election,

Kiai's political communication and orientations have become the partisans' primary roles among $P K B$ 's constituents.
\end{abstract}

Kata kunci: "platform", identitas partai, komunikasi politik kiai, partisan, loyalitas primordial

\section{Pendahuluan}

Kemunculan Partai Kebangkitan Bangsa (PKB) dalam pusaran arus politik partai pasca Orde Baru menarik dikaji karena dua alasan berikut. Pertama, keterlibatan Pengurus Besar Nahdlatul Ulama (PBNU) dalam membidani kelahiran PKB mengisyaratkan keseriusannya dalam mengarahkan suara warga Nahdlatul Ulama (NU). Lebih dari sekadar merestui, keterlibatan PBNU dapat dibaca sebagai kesungguhan dalam melahirkan sang "putra mahkota". Padahal, aspirasi politik nahdliyin tidak benar-benar monolit. Partai politik yang lahir dari rahim NU bukan hanya PKB. Hal ini memunculkan dugaan adanya kesadaran yang mempersatukan dan mendesak warga NU untuk sementara - hanya akan berkhidmat pada PKB.
Kedua, dibanding partai baru lainnya, $\mathrm{PKB}$ adalah peraih suara terbanyak pada Pemilu 1999. Perolehan suara PKB mendekati raihan suara Partai NU pada Pemilu 1955. Jumlah ini melampaui raihan suara Partai Persatuan Pembangunan (PPP), yang sudah hadir sejak Orde Baru dan merupakan hasil fusi NU dengan Partai Muslimin Indonesia (Parmusi), Partai Syarikat Islam Indonesia (PSII), dan Persatuan Tarbiyah Indonesia (Perti), pada 5 Januari 1973.

Kembalinya NU ke kancah politik menarik dikaji, karena sejak 1984 NU memutuskan kembali ke khittah 1926. Keputusan ini bukan hanya mengharuskan NU menanggalkan atribut partai, tetapi juga menegaskan kembali jati dirinya sebagai organisasi sosial keagamaan (jam'iyyah diniyah). Fenomena ini memunculkan pertanyaan, faktor apa 
yang membuat dukungan terhadap PKB yang dianggap sebagai "titisan" Partai NU ini relatif stabil, padahal deideologisasi yang dijalankan Orde Baru berlangsung sangat intensif?

\section{Metode Penelitian}

Kemunculan PKB sebagai pemenang ketiga di bawah Partai Demokrasi Indonesia Perjuangan (PDIP) dan Partai Golongan Karya (Golkar), atau terbesar dibandingkan seluruh partai yang muncul pasca-Orde Baru, mengisyaratkan adanya gejala "reinkarnasi" politik NU yang tidak sempurna. Dugaan ini muncul karena kelahiran PKB dibidani NU, sehingga PKB menjadi anak emas NU. Namun, perolehan suara PKB yang jauh di bawah jumlah pemilih yang diasumsikan berhaluan NU menyiratkan dukungan warga NU terhadap PKB tidak bulat.

Selain menguatnya isu primordial, kemunculan partai politik menjelang Pemilu 1999 ditandai absennya platform yang dapat menggugah partisipasi publik. Fenomena ini memunculkan dugaan bahwa keputusan yang diambil pemilih saat memberikan suara dan loyalitas yang terbangun di kalangan para anggota lebih didasarkan atas pertimbangan di luar pemahaman mereka tentang platform partai.

Penelitian ini menggunakan metode studi kasus sebagai salah satu tradisi kualitatif(Creswell, 1998: 63) dengan pendekatan proses (Combs, 1981: 39-66). Proses sosialisasi platform pluralitas Partai Kebangkitan Bangsa (PKB) dan komunikasi politik kiai dalam membentuk identifikasi kepartaian dijadikan kasus dalam penelitian ini.

Data primer dalam penelitian ini dikumpulkan melalui wawancara terhadap 16 informan kunci dan beberapa kelompok informan yang digali dalam bentuk diskusi (focus group discussion). Untuk menghindari "bias partai", informasi dikumpulkan pula dari politisi NU yang berkiprah di luar PKB, seperti di PPP, Golkar, Partai Bintang Reformasi, dan PAN.

Informan ditentukan secara snowball, sehingga lokasi penelitian bergantung kepada di mana informan berada atau peristiwa politik yang digelar PKB berlangsung. Bandung, Jakarta, Cirebon, Sukabumi, Sampang, Pasuruan, dan Surabaya, sebagai daerah yang dikenal sebagai basis PKB menjadi daerah penelitian yang utama, serta Nusa Tenggara Timur (NTT), sebagai daerah percontohan pengembangan wawasan kebangsaan ala PKB.

Selain digali melalui wawancara mendalam, data primer dihimpun melalui pengamatan terlibat terhadap sejumlah objek dan peristiwa. Untuk kepentingan penelitian ini, telah dilakukan pengamatan dan wawancara dengan para pelaku yang terlibat dalam perumusan calon anggota legislatif dan kampanye menjelang Pemilu 2004. Berbagai forum yang bertujuan mematangkan calon presiden yang akan dimajukan PKB dan kampanye pemilihan presiden menjadi peristiwa yang penting.

Sementara, data sekunder dihimpun dari informasi kepustakaan, baik dari buku teks, jurnal ilmiah, hasil penelitian, laporan, dan dokumen; baik yang diterbitkan untuk umum maupun dokumen yang diterbitkan untuk kalangan internal PKB. Keseluruhan hasil penelitian kepustakaan menjadi sumber data yang penting bagi penelusuran polapola partisipasi dan komunikasi politik NU. Penelusuran data dokumenter difokuskan kepada keterlibatan ulama/kiai dalam wilayah politik serta akar-akar tradisi yang menjadi rujukan penyusunan platform.

Keseluruhan data dihimpun mulai September 2003 hingga Juni 2005. Data final yang dianalisis dan disajikan adalah data yang telah diseleksi melalui member checking.

\section{Genesis "Platform" dan Filogeni Politik PKB}

Bila dilihat dari kulturnya, PKB bukan entitas yang benar-benar baru. PKB hanya mewadahi sesuatu yang sudah ada, yakni komunitas NU dengan segenap sistem nilai yang dianutnya. Meskipun tidak terdapat hubungan organisatoris antara NU dan PKB, namun di antara keduanya sulit dipisahkan. PKB memang bukan organisasi yang dibentuk dengan tugas melaksanakan pro- 
gram-program NU, namun secara embrional PKB dan NU dihubungkan oleh "plasenta" yang sulit diputus.

Keterlibatan PBNU dalam membidani kelahiran PKB sampai pada derajat dituduh melanggar Khittah 1926, mengimplikasikan hal-hal berikut. Pertama, hasrat politik NU tidak padam karena langkah penarikan diri dari wilayah politik praktis. Hasrat berpolitik warga nahdliyin pun tidak tergerus deideologisasi yang diterapkan rezim Orde Baru. Bahkan langkah ini terbukti menjadi titik tolak ploriferasi politik NU.

Kedua, keputusan NU memfasilitasi pembentukan PKB merupakan bentuk adaptabilitas sikap politik NU. Fleksibilitas sikap politik NU terlihat di sepanjang sejarah pertumbuhan NU. Baik sebagai organisasi kemasyarakatan (jam'iyyah diniyah) maupun sebagai partai politik, sikap politik NU terkenal lentur. Meskipun dalam kasus tertentu NU tampil radikal (seperti menolak Perjanjian "Linggarjati" dan "Renville" atau ketika menolak Mutual Secutity Act dan dewan keamanan bersama yang pro AS pada 1952), namun watak akomodatif lebih mewarnai sikap politik NU.

Keterbukaan yang digagas para pendiri PKB dilandasi pandangan bahwa corak partai politik masa depan adalah lintas etnis, jauh melampaui keanggotaan sebuah organisasi kemasyarakatan. Pandangan ini menempatkan Pancasila sebagai asas partai, sekaligus menempatkan Islam sebagai akhlak masyarakat (etika sosial), dan sumber materi perundangan.

Beberapa dasar pertimbangan menyangkut pemilihan nama partai mengisyaratkan bahwa secara kultur PKB mengadopsi sikap kemasyarakatan yang dikembangkan NU. Kultur PKB adalah kultur NU, karena PKB adalah pengorganisasian kultur NU secara politik. Kultur Islam ahlussunnah wal Jama'ah menjadi basis historis dan ideologis PKB, yang bersenyawa dengan sejarah perjalanan kebangsaan dan kenegaraan Indonesia.

Namun, tidak semua warga NU memiliki pandangan yang sejalan dengan para pendiri PKB. Beberapa ulama mengritik karakter PKB yang terlalu berorientasi kebangsaan dan tidak secara tegas meneruskan tradisi politik Partai NU. Hal ini mengisyaratkan bahwa sikap politik warga NU tidak monolit. Mereka memiliki pemahaman yang beragam tentang bagaimana seharusnya tradisi politik NU ditransformasikan ke dalam praksis politik masa kini. Keragaman tadi telah mendorong munculnya beragam partai yang memiliki sejarah kekerabatan dengan NU (filogeni).

Filogeni politik PKB tidak didorong oleh perbedaan ideologis di antara empat partai yang lahir di kalangan NU. Perbedaan tadi hanya memperlihatkan "jalan yang berbeda menuju tujuan yang sama". Selain karena friksi yang terjadi di kalangan elit NU, kemunculan partai tersebut lebih disebabkan perbedaan penafsiran tentang bagaimana seharusnya sistem nilai yang dianut NU ditransformasikan ke dalam wilayah politik. Perbedaan tadi melemahkan barisan politik NU. Kekuatan NU terpecah ke dalam sekutu-sekutu kecil yang mudah digilas kekuatan lain.

Mabda Siyasiy memberikan gambaran jelas tentang hakikat PKB dan garis perjuangannya. Ideologi humanisme religius bukan hanya berakar pada fitrah manusia, tetapi juga mempertimbangkan taraf perkembangan manusia dalam konteks sosial. Paradigma humanisme berakar pada hakikat manusia yang suci, cenderung pada hal-hal yang baik, keunggulan indrawi dan memiliki akal. Sedangkan dimensi religius berkaitan dengan hidayah wahyu, pertolongan, dan petunjuk Allah swt. Artinya, selain menerima nilai-nilai yang diturunkan Allah swt, PKB pun menyerap nilainilai yang tumbuh dari perkembangan manusia.

Mengacu kepada sistem nilai yang terkandung di dalam Mabda Siyasiy jelas bahwa partai yang dikehendaki adalah partai yang terbuka. Meski naskah ini dirumuskan para tokoh NU, namun PKB tidak dimaksudkan sebagai reinkarnasi Partai NU. Berbeda dengan Partai NU yang pada awalnya mencita-citakan terwujudnya syari'at Islam dalam tatanan kenegaraan, PKB tidak mengusung formalisme Islam. Bagi PKB, mengambil sari pati nilai-nilai Islam untuk diangkat ke dalam hukum positiflebih diutamakan daripada menjadikan syari'at Islam sebagai dasar negara.

Kiai menjadi simbol signifikan dalam 
komunikasi politik PKB. Di antara para kiai, Abdurrahman Wahid masih menjadi primus inter pares. Figuritas Gus Dur bukan hanya dibentuk oleh keunggulan dari segi nasab, tetapi juga didukung oleh keluasan pengetahuan, paham pluralitasnya, dan sensitivitas terhadap budaya lokal. Pemerintahan Wahid yang hanya 21 bulan menjadi eksperimen implementasi platform pluralitas PKB.

Demokrasi dan penguatan masyarakat sipil (civil society) menjadi kredo (paham) pemerintahan Abdurrahman Wahid. Hal ini terlihat dari wacana dan langkah-langkah politik yang diambil Abdurrahman Wahid dalam 21 bulan kepemimpinannya.

Ide membangun kemandirian masyarakat sehingga tidak bergantung sepenuhnya kepada negara (otonomi relatif warga negara) menjadi gagasan besar Abdurrahman Wahid. Gagasan tadi diterjemahkan ke dalam wacana (kesatuan tutur) supremasi sipil, kemerdekaan pers dan kebebasan berbicara, pembelaan hak minoritas, penguatan posisi masyarakat di hadapan negara, supremasi hukum, dan deformalisasi Islam.

Selain mengembangkan wacana di atas, Abdurrahman Wahid pun melakukan "ijtihad" dalam hal hubungan penguasa dan rakyatnya. Kepala negara yang sebelumnya "sulit disentuh", dicitrakan sebagai terbuka dan dekat dengan rakyat. Hal ini paling tidak terlihat dari tindakannya melakukan desakralisasi istana dan memajukan informalitas komunikasi politik.

\section{Identifikasi Kepartaian}

Terlepas dari perolehan suara PKB yang masih kecil, langkah-langkah yang ditempuh kader PKB NTT memperlihatkan fenomena menarik. Fenomena tadi dalam beberapa hal mirip langkahlangkah yang ditempuh pengurus PKB di Jawa dengan spektrum yang berbeda.

Pertama, seperti halnya di Jawa, di NTT figur Gus Dur menjadi faktor penentu. Bukan platform yang memikat mereka. Figur Gus Dur yang dinilai mampu memberi keteduhan bagi warga Kristiani menawan mereka.
Kedua, seperti halnya di Jawa, identifikasi kepartaian belum terbentuk. Pemanfaatan struktur keagamaan Kristen sebagai strategi perluasan dukungan mendekati pola rekrutmen di Jawa yang memanfaatkan jaringan pesantren. Dengan kata lain, baik di Jawa maupun di NTT yang terjadi adalah transformasi kesetian primordial ke wilayah politik.

Ketiga, pemanfaatan pranata budaya sebagai media komunikasi politik. Ke dalamnya termasuk melakukan politik kultural dengan memanfaatkan opinion leaders, baik dalam wilayah adat maupun agama. Hal ini dimungkinkan karena masyarakat NTT terstruktur secara hierarkhis dengan raja dan kepala suku sebagai patronnya. Realitas terakhir, lagi-lagi, memiliki kemiripan dengan struktur masyarakat Jawa yang sentris, meski yang menjadi patron bukan kepala suku.

Keempat, selain menarik simpati masyarakat yang terlanjur jatuh hati pada Partai Golkar dan PDIP (orientasi merah-kuning) tantangan yang dihadapi kader PKB NTT adalah pencitraan. Citra PKB sebagai partai Islam melekat cukup kuat di benak masyarakat NTT. Citra seperti ini tidak menunjang pemasaran politik PKB. Karena itu, langkah yang ditempuh adalah mengarusutamakan citra PKB sebagai partai terbuka, nasionalis, dan demokratis. Namun dalam praktiknya, strategi tadi berbentuk deislamisasi, yakni mengurangi simbolsimbol keislaman.

Fenomena terakhir, berbeda kontras dengan realitas PKB di Jawa, khususnya Tapal Kuda. Namun, keduanya menemukan titik temu, yakni isu agama dan primordial menjadi "kartu" yang menentukan. Inilah dilema PKB dalam membangun demokrasi. Membangun demokrasi tidak bisa berlandaskan primordialisme, sebab nalar demokrasi menuntut egalitarianisme, transparansi, dan tanpa diskriminasi dalam semua bidang.

\section{Pola Komunikasi Politik Kiai}

Meskipun PKB bersifat terbuka dan dihuni oleh orang-orang dengan latar belakang budaya yang beragam, namun kultur NU tetap dominan. Dalam berbagai acara yang digelar PKB, baik di 
pusat maupun di daerah, kultur dan simbol NU masih menjadi mainstream (arus utama). Pembacaan shalawat dalam acara-acara yang digelar PKB adalah indikasi penetrasi kultur NU terhadap budaya komunikasi PKB.

Budaya NU menjadi rujukan reproduksi simbol-simbol PKB. Simbol-simbol PKB adalah modifikasi simbol-simbol NU yang ditransformasikan ke dalam lingkungan yang lebih luas. Proses transformatif tadi dapat dilukiskan dalam gambar berikut.

Kiai menjadi nucleus (unsur inti) komunitas pesantren dan NU. Pada gilirannya, ketiga unsur ini menjadi sumber dan rujukan dalam proses reproduksi simbol-simbol PKB. Dengan kata lain, simbol PKB adalah simbol-simbol NU yang telah mengalami metamorfosis. Di dalam proses ini, kiai yang berorientasi politik (political-oriented kiai) menjadi agen yang mempersambungkan prosesproses transformatif tadi.

Introduksi cara-cara modern (modernisasi) yang melanda warga NU - seperti yang ditandai oleh kahadiran struktur modern - belum mengubah pola-pola relasi yang sudah ada. Bahkan, ikatan terhadap faktor-faktor primordial menguat sejalan dengan pelekatan diri mereka terhadap struktur formal yang mereka ciptakan. Fenomena inilah yang menimbulkan kecenderungan munculnya etnisitas dalam politik (political ethnicity).

Modernisasi yang dijalani PKB tidak ditempuh dengan cara mengikis pola hubungan yang sudah ada, melainkan hanya memfungsikan kembali struktur-struktur tradisional yang sudah diwarisi. Faktor nasab, etnis, dan usia, masih menjadi unsur primer dalam alokasi kekuasaan. Diferensiasi antara wilayah politik dan religius hampir tidak terjadi. Hal ini dimungkinkan karena teologi sosial politik yang dianut amat fleksibel dalam menghadapi perubahan-perubahan yang muncul akibat politik modernisasi yang ditempuh PKB.

Sebagai pengorganisasian kultur NU secara politik, PKB mewarisi kerangka berpikir khas NU, yang tidak lain adalah organisasi sosial keagamaan (jam'iyyah ijtima'iyyah diniyyah). Kerangka berpikir tadi tampak dalam ciri-ciri primer NUdan dalam kiprah politiknya. Ciri-ciri primer tadi ditransformasikan ke dalam praksis politik PKB sehingga menjadi basis identifikasi kepartaian, terutama di daerah-daerah yang dikenal basis NU. Namun, sebagai partai politik yang dimaksudkan sebagai alat transformasi sosial politik NU, PKB dituntut memiliki sensitivitas terhadap nilai sosial politik yang relevan dengan kaidah-kaidah yang dianut NU.

Secara normatif, kerangka berpikir tadi ditemukan di dalam dokumen-dokumen historis PKB, tempat di mana ideologi politik PKB dituangkan. Preferensi tentang masyarakat dan negara yang dicita-citakan PKB bukan hanya berbasis pada etika dan nilai-nilai keagamaan, tetapi juga tidak sekuler - dalam arti memisahkan kehidupan bernegara dari kehidupan beragama meski sejak awal PKB tidak menghendaki formalisasi Islam.

Dilihat dari konteks di atas, sifat terbuka yang dianut PKB berkonotasi sebagai quasi terbuka, atau dalam bahasa para kiai di Jawa Timur sebagai "terbuka yang tertutup". Keterbukaan PKB berlaku sampai pada titik tidak mengganggu sistem nilai yang dianut NU. Sederhananya, PKB bersifat tertutup terhadap anasir-anasir yang merusak kaidah dasar yang dianut warga NU.

Dengan kata lain, quasi terbuka bermakna PKB itu inklusif sekaligus ekslusif. Inklusif dalam hal muamalah dan interaksi sosial, tetapi eksklusif dalam hal ibadah dan akidah. Kaidah ini bermakna bahwa PKB dapat menggelar kegiatan muamalah dan interaksi sosial tanpa membedakan agama dan latar belakang sosial budaya. Namun, PKB harus membatasi diri pada hal-hal yang menyangkut ibadah dan akidah.

Dalam hubungannya dengan anasir-anasir agama yang membentuk konfigurasi dukungan bagi PKB, keterbukaan harus dipahami sebagai sikap toleran (tasamuh) terhadap agama mana pun tanpa meninggalkan keyakinan teologisnya sendiri. Di dalam wilayah ibadah dan akidah, PKB tidak memiliki otoritas untuk ikut campur, meski tidak akan pernah terlepas sama sekali.

Karena itu, platform pluralitas PKB menuntut manajemen komunikasi tersendiri dalam proses 
sosialisasinya mengingat fakta bahwa PKB telah secara nyata membuka basis dukungan di kalangan non NU, bahkan non-Islam. Manajemen komunikasi PKB perlu dirancang paling tidak untuk dua kebutuhan.

Pertama, memelihara dukungan pemilih dari kalangan Muslim yang menjadi captive market, sekaligus menarik dukungan non-Muslim lewat penampilan sosok partai yang moderat. Sebelum menarik kelompok kedua, PKB harus mempertahankan dukungan kelompok pertama dengan meyakinkan bahwa format "Islam Kebangsaan" yang dianut NU dan diwarisi PKB adalah salah satu bentuk jawaban dalam mengatasi berbagai persoalan, khususnya dalam masalah relasi agama dan negara.

Sosok partai yang moderat menjadi daya tarik PKB di kalangan non-Muslim, paling tidak di Nusa Tenggara Timur. Beberapa pemilih PKB di kota Kupang mengaku tertarik pada PKB karena mampu memberi kesejukan bagi warga Kristiani, yang dalam kehidupan nasional menjadi minoritas. Sayangnya, eksperimen PKB menarik dukungan non-Muslim tidak dapat meningkatkan raihan suara PKB secara signifikan dalam Pemilu 2004. Bahkan, secara nasional raihan suara PKB menurun bila dibandingkan Pemilu 1999.

Kedua, menggeser kekuatan PKB dari anasiranasir yang bersifat primordial ke arah keunggulan kompetitifyang berlandaskan kultur, program, dan kepemimpinan. Namun, transformasi nilai tadi tidak bisa dilakukan secepat membalikkan telapak tangan karena ia menyangkut atribut sosial yang telah terlanjur dianggap sebagai pandangan hidup (ways of life).

Dikaji dari perspektif tadi, sosialisasi platform pluralitas PKB bertolak dari keyakinan bahwa akidah dan ritus ibadah setiap agama adalah hak ekslusif setiap pemeluknya. Wilayah ini merupakan area privat, yang tidak menjadi otoritas PKB untuk merekayasanya. Sosialisasi platform pluralitas PKB tidak menjangkau wilayah akidah dan ibadah, meskipun senantiasa mendapatkan penetrasi, bahkan dengan sengaja menyerap, nilai agama yang ditransformasikan ke dalam gelanggang politik.
Dengan demikian, medan khidmat sosialisasi platform pluralitas PKB adalah wilayah muamalah dan interaksi sosial, yakni seperangkat panduan sosial yang diturunkan dari nilai-nilai keagamaan dan berlaku universal. Mengacu kepada rumusan platform $\mathrm{PKB}$, nilai-nilai dasar dimaksud mencakup beberapa hal. Kesatu, jaminan penegakan HAM dan kejujuran besumber hati nurani (as-shidqu). Kedua, mengembangkan sikap dapat dipercaya, setia dan tepat janji. Ketiga, menciptakan tatanan masyarakat yang mampu memecahkan masalah sosial (al-amanah wa al-wafau bi al-ahdli), adil (al-'adalah), tolong-menolong (al-ta'awun), konsisten (al-istiqamah), musyawarah (al-syura), dan kesamaan kedudukan di muka hukum (almusawa).

Fakta bahwa tidak semua orang yang mengidentifikasikan dirinya dengan NU memilih PKB menunjukkan bahwa keputusan untuk memilih tidak semata-mata ditentukan oleh kekuatankekuatan dari luar. Demikian pula fakta bahwa sejumlah non-Muslim yang memutuskan memilih PKB menunjukkan bahwa tindakan politik mereka tidak tunduk pada pencitraan yang mengesankan PKB sebagai partai orang Islam. Kedua fakta ini mengisyaratkan bahwa tindakan politik warga PKB melibatkan proses interpretatif atas simbol-simbol yang dipertukarkan ketika proses komunikasi politik berlangsung.

Dikaji dari perspektif interaksi simbolik, sosialisasi platform pluralitas PKB akan bergantung kepada kualitas hubungan dan kelangsungan interaksi, di mana kedua pihak (aktivis, politisi, dan komunikator profesional versus khalayak, simpatisan, dan konstituen PKB) saling menukar makna dan kelakuan. Sebuah transaksi politik yang di dalamnya melibatkan proses penciptaan kesan melalui proses impression management (Goffman, 1959: 203).

Penataan kesan menjadi kunci keberhasilan politisi dalam serangkaian proses transasksi politik, karena sejak lama diyakini bahwa banyak aspek politik berupa penampilan (appearance). Para politikus beraksi di depan publik sedemikian rupa, sehingga mereka menganggapnya sebagai orang penting, pintar, dan layak dipercaya untuk 
mengemban amanah. Para pemimpin dan aktivis partai politik harus memainkan peran seperti yang dibayangkan khalayak. Mereka akan selalu menemukan banyak orang yang siap "dikelabui". Mereka menjanjikan sesuatu, sehingga mereka dikesani sebagai sosok yang merasakan sesuatu serta berpikir dan bertindak menurut apa yang dibayangkan konstituennya.

\section{Kesimpulan}

Pertumbuhan politik kepartaian di Indonesia tidak identik dengan sekularisasi, melainkan transformasi kesadaran religius ke dalam wilayah politik. Keyakinan bahwa urusan politik dapat diatur dan ditentukan oleh kehendak manusia sendiri tidak menafikan hak prerogatif Tuhan dalam keseluruhan proses tersebut.

Komunikasi internal dan esksternal yang tidak efektif menyebabkan substansi platform tidak tersosialisasikan dengan baik. Akibatnya keberadaan platform menjadi tidak fungsional. Platform menjadi atribut yang menunjang penampilan politisi dalam panggung depan. Kedudukan platform tergantikan oleh figur yang menjadi ikon (icon) sekaligus ruh partai. Kondisi ini melahirkan pola komunikasi politik yang melekatkan kredibilitas komunikator pada faktor-faktor yang diwariskan (askriptif) dan menempatkan figur sebagai mesiah. Pola ini mengukuhkan budaya konteks tinggi (high contex) yang ditandai oleh penggunaan kode terbatas (restricted codes). Spektrum komunikasi internal dan eksternal partai yang tidak egaliter bukan hanya menjadikan klaim inklusivitas sebagai keterbukaan semu (quasi terbuka), tetapi juga mempertajam segregasi antarfaksi, sehingga partai menjadi mudah terfragmentasi ke dalam kekuatan sempalan.

Penguasaan sumber daya komunikasi partai politik yang terpusat di tangan figur melahirkan kepemimpinan partai yang mesianik. Pola ini bukan hanya melekatkan otoritas kepemimpinan pada tradisi dan kharisma sebagaimana lazim dianut selama ini, tetapi juga menempatkan figur sebagai mesiah (ratu adil) yang tidak pernah berbuat salah.
Kepemimpinan mesianik dikukuhkan oleh pola orientasi pengikut yang bercorak parokhial dan rekrutmen yang berdasar kepada nasab sehingga kelahiran dan perkawinan menjadi alat promosi karier yang penting. Sedemikian pentingnya peran politik keluarga-penguasa, maka perhatian para pencari kekuasaan tertuju pada pola kekuasaan keluarga sebagai miniatur pola kekuasaan partai. Partai sulit memainkan perannya sebagai representasi kepentingan pengikut, melainkan hanya mengukuhkan dominasi kaukus yang dibentuk tokoh-tokoh senior partai (gerontocracy). Kecenderungan ini mengukuhkan keberlakuan hukum besi oligarkhi, dimana aristokrat tradisional berperan sebagai oligoi-oligoi yang mengendalikan partai.

Pola komunikasi politik yang askriptif dan kepemimpinan mesianik menyebabkan tidak terbangunnya wacana kritis di kalangan fungsionaris dan simpatisan partai. Identifikasi kepartaian tidak terbangun atas penguasaan nilai dasar dan cita-cita partai, melainkan merupakan bentuk transformasi kesetiaan primordial ke dalam praksis politik. Involusi politik ini dikukuhkan oleh pola sosialisasi yang menempatkan kepatuhan di atas pertimbangan rasional. Manipulasi simbolsimbol agama dan budaya menjadi unsur primer dalam komunikasi antara pemimpin dengan pengikut sekaligus menjadi alat dominasi dan mobilisasi dukungan yang penting. Pola komunikasi tadi ditandai oleh pemakaian alat-alat retorika (baik verbal maupun nonverbal) yang bersumber dari - atau adaptasi bentuk ritual - agama dan budaya sehingga pemaknaan atas simbolsimbol tersebut bersifat isoterik sesuai dengan pengalaman religio-politik penggunanya.

Proses tersebut bukan hanya memberi peluang terjadinya kesalahpahaman, tetapi juga menguatkan kecenderungan menjadikan agama dan budaya sebagai alat justifikasi keputusan dan tindakan politik. Prinsip "ekonomi pernyataan" bukan hanya dapat mengurangi risiko keterpurukan citra akibat kesalahan manajemen komunikasi, tetapi juga dapat menambah daya persuasi komunikasi politik. 


\section{Daftar Pustaka}

Alwasilah, A. Chaedar. 2002. Pokoknya Kualitatif: Dasar-dasar Merancang dan Melakukan Penelitian Kualitatif. Jakarta: Pustaka Jaya.

Combs, James E \& Dan Nimmo 1981. A Primer of Politics. New York: Macmillan Publishing Company.

Creswell, John W. 1994. Research Design: Qualitative \& Quantitative Approaches. California: SAGE Publications.

1998. Qualitative Inquiry and Research Design: Choosing Among Five Traditions. California: SAGE Publications.

Feith, Herbert. 1962. The Decline of Constitutional Democracy in Indonesia. New York: Cornell University Press.

Feith, Herbert \& Lance Castles. 1970. Indonesian Political Thinking 1945-1965. USA: Cornell University.

Geertz, Clifford. 1981. Abangan, Santri, Priyayi dalam Masyarakat Jawa. Jakarta: Pustaka Jaya.

1992. Kebudayaan \& Agama, terjemahan Francisco Budi Hardiman. Yogyakarta: Kanisius.
1963. Old Societies and New States: The Quest for Modernity in Asia and Africa, The Free Press of Glencoe.

Goffman, Erving. 1974. The Presentation of Self ini Everyday Life. USA: Penguin Books.

Lewellen, Ted C. 1982. Political Anthropology, Berger L. Carey Publisher.

Martindale, Don. 1960. The Nature and Types of Sociological Theory, Cambridge, Massachusetts, The Riverside Press.

Mulyana, Deddy. 2001. Metode Penelitian Kualitatif: Paradigma Baru Ilmu Komunikasi dan Ilmu Sosial Lainnya. Bandung: Remaja Rosdakarya.

Nimmo, Dan D. dan Keith R. Sanders. 1981. Handbook of Political Communication. California: Sage Publication, Inc.

1978. Political Communication and Public Opinion in America. California: Goodyear Publishing Company.

Sherman, Arnolk K, dan Aliza Kolker. 1987. The Social Bases of Politics. Belmont: Wardworth Publishing Company, 


\title{
Transformasi Loyalitas Primordial sebagai Basis Identifikasi Kepartaian: Kasus Partai Kebangkitan Bangsa dalam Pemilihan Umum 1999 dan 2004
}

\author{
Karim Suryadi
}

ABSTRACT

\begin{abstract}
Transformation of primordial loyalty into the political sphere rather than understanding of the substance of the party's platform is a key factor for PKB's (National Awakening Party) devotees to adhere to the party. The platform has not been effectively socialized. The practice of the party has not been believed as a requisite condition to create an order society. On the other hand, adhering to Nahdlatul Ulama (NU) and inclining to submit to orders or wishes of Kiai (Muslim Scholars) is believed among PKB's voters as a means by which a good community is created (khoerul barriyah). Therefore, since the 2004 General Election,

Kiai's political communication and orientations have become the partisans' primary roles among $P K B$ 's constituents.
\end{abstract}

Kata kunci: "platform", identitas partai, komunikasi politik kiai, partisan, loyalitas primordial

\section{Pendahuluan}

Kemunculan Partai Kebangkitan Bangsa (PKB) dalam pusaran arus politik partai pasca Orde Baru menarik dikaji karena dua alasan berikut. Pertama, keterlibatan Pengurus Besar Nahdlatul Ulama (PBNU) dalam membidani kelahiran PKB mengisyaratkan keseriusannya dalam mengarahkan suara warga Nahdlatul Ulama (NU). Lebih dari sekadar merestui, keterlibatan PBNU dapat dibaca sebagai kesungguhan dalam melahirkan sang "putra mahkota". Padahal, aspirasi politik nahdliyin tidak benar-benar monolit. Partai politik yang lahir dari rahim NU bukan hanya PKB. Hal ini memunculkan dugaan adanya kesadaran yang mempersatukan dan mendesak warga NU untuk sementara - hanya akan berkhidmat pada PKB.
Kedua, dibanding partai baru lainnya, $\mathrm{PKB}$ adalah peraih suara terbanyak pada Pemilu 1999. Perolehan suara PKB mendekati raihan suara Partai NU pada Pemilu 1955. Jumlah ini melampaui raihan suara Partai Persatuan Pembangunan (PPP), yang sudah hadir sejak Orde Baru dan merupakan hasil fusi NU dengan Partai Muslimin Indonesia (Parmusi), Partai Syarikat Islam Indonesia (PSII), dan Persatuan Tarbiyah Indonesia (Perti), pada 5 Januari 1973.

Kembalinya NU ke kancah politik menarik dikaji, karena sejak 1984 NU memutuskan kembali ke khittah 1926. Keputusan ini bukan hanya mengharuskan NU menanggalkan atribut partai, tetapi juga menegaskan kembali jati dirinya sebagai organisasi sosial keagamaan (jam'iyyah diniyah). Fenomena ini memunculkan pertanyaan, faktor apa 
yang membuat dukungan terhadap PKB yang dianggap sebagai "titisan" Partai NU ini relatif stabil, padahal deideologisasi yang dijalankan Orde Baru berlangsung sangat intensif?

\section{Metode Penelitian}

Kemunculan PKB sebagai pemenang ketiga di bawah Partai Demokrasi Indonesia Perjuangan (PDIP) dan Partai Golongan Karya (Golkar), atau terbesar dibandingkan seluruh partai yang muncul pasca-Orde Baru, mengisyaratkan adanya gejala "reinkarnasi" politik NU yang tidak sempurna. Dugaan ini muncul karena kelahiran PKB dibidani NU, sehingga PKB menjadi anak emas NU. Namun, perolehan suara PKB yang jauh di bawah jumlah pemilih yang diasumsikan berhaluan NU menyiratkan dukungan warga NU terhadap PKB tidak bulat.

Selain menguatnya isu primordial, kemunculan partai politik menjelang Pemilu 1999 ditandai absennya platform yang dapat menggugah partisipasi publik. Fenomena ini memunculkan dugaan bahwa keputusan yang diambil pemilih saat memberikan suara dan loyalitas yang terbangun di kalangan para anggota lebih didasarkan atas pertimbangan di luar pemahaman mereka tentang platform partai.

Penelitian ini menggunakan metode studi kasus sebagai salah satu tradisi kualitatif(Creswell, 1998: 63) dengan pendekatan proses (Combs, 1981: 39-66). Proses sosialisasi platform pluralitas Partai Kebangkitan Bangsa (PKB) dan komunikasi politik kiai dalam membentuk identifikasi kepartaian dijadikan kasus dalam penelitian ini.

Data primer dalam penelitian ini dikumpulkan melalui wawancara terhadap 16 informan kunci dan beberapa kelompok informan yang digali dalam bentuk diskusi (focus group discussion). Untuk menghindari "bias partai", informasi dikumpulkan pula dari politisi NU yang berkiprah di luar PKB, seperti di PPP, Golkar, Partai Bintang Reformasi, dan PAN.

Informan ditentukan secara snowball, sehingga lokasi penelitian bergantung kepada di mana informan berada atau peristiwa politik yang digelar PKB berlangsung. Bandung, Jakarta, Cirebon, Sukabumi, Sampang, Pasuruan, dan Surabaya, sebagai daerah yang dikenal sebagai basis PKB menjadi daerah penelitian yang utama, serta Nusa Tenggara Timur (NTT), sebagai daerah percontohan pengembangan wawasan kebangsaan ala PKB.

Selain digali melalui wawancara mendalam, data primer dihimpun melalui pengamatan terlibat terhadap sejumlah objek dan peristiwa. Untuk kepentingan penelitian ini, telah dilakukan pengamatan dan wawancara dengan para pelaku yang terlibat dalam perumusan calon anggota legislatif dan kampanye menjelang Pemilu 2004. Berbagai forum yang bertujuan mematangkan calon presiden yang akan dimajukan PKB dan kampanye pemilihan presiden menjadi peristiwa yang penting.

Sementara, data sekunder dihimpun dari informasi kepustakaan, baik dari buku teks, jurnal ilmiah, hasil penelitian, laporan, dan dokumen; baik yang diterbitkan untuk umum maupun dokumen yang diterbitkan untuk kalangan internal PKB. Keseluruhan hasil penelitian kepustakaan menjadi sumber data yang penting bagi penelusuran polapola partisipasi dan komunikasi politik NU. Penelusuran data dokumenter difokuskan kepada keterlibatan ulama/kiai dalam wilayah politik serta akar-akar tradisi yang menjadi rujukan penyusunan platform.

Keseluruhan data dihimpun mulai September 2003 hingga Juni 2005. Data final yang dianalisis dan disajikan adalah data yang telah diseleksi melalui member checking.

\section{Genesis "Platform" dan Filogeni Politik PKB}

Bila dilihat dari kulturnya, PKB bukan entitas yang benar-benar baru. PKB hanya mewadahi sesuatu yang sudah ada, yakni komunitas NU dengan segenap sistem nilai yang dianutnya. Meskipun tidak terdapat hubungan organisatoris antara NU dan PKB, namun di antara keduanya sulit dipisahkan. PKB memang bukan organisasi yang dibentuk dengan tugas melaksanakan pro- 
gram-program NU, namun secara embrional PKB dan NU dihubungkan oleh "plasenta" yang sulit diputus.

Keterlibatan PBNU dalam membidani kelahiran PKB sampai pada derajat dituduh melanggar Khittah 1926, mengimplikasikan hal-hal berikut. Pertama, hasrat politik NU tidak padam karena langkah penarikan diri dari wilayah politik praktis. Hasrat berpolitik warga nahdliyin pun tidak tergerus deideologisasi yang diterapkan rezim Orde Baru. Bahkan langkah ini terbukti menjadi titik tolak ploriferasi politik NU.

Kedua, keputusan NU memfasilitasi pembentukan PKB merupakan bentuk adaptabilitas sikap politik NU. Fleksibilitas sikap politik NU terlihat di sepanjang sejarah pertumbuhan NU. Baik sebagai organisasi kemasyarakatan (jam'iyyah diniyah) maupun sebagai partai politik, sikap politik NU terkenal lentur. Meskipun dalam kasus tertentu NU tampil radikal (seperti menolak Perjanjian "Linggarjati" dan "Renville" atau ketika menolak Mutual Secutity Act dan dewan keamanan bersama yang pro AS pada 1952), namun watak akomodatif lebih mewarnai sikap politik NU.

Keterbukaan yang digagas para pendiri PKB dilandasi pandangan bahwa corak partai politik masa depan adalah lintas etnis, jauh melampaui keanggotaan sebuah organisasi kemasyarakatan. Pandangan ini menempatkan Pancasila sebagai asas partai, sekaligus menempatkan Islam sebagai akhlak masyarakat (etika sosial), dan sumber materi perundangan.

Beberapa dasar pertimbangan menyangkut pemilihan nama partai mengisyaratkan bahwa secara kultur PKB mengadopsi sikap kemasyarakatan yang dikembangkan NU. Kultur PKB adalah kultur NU, karena PKB adalah pengorganisasian kultur NU secara politik. Kultur Islam ahlussunnah wal Jama'ah menjadi basis historis dan ideologis PKB, yang bersenyawa dengan sejarah perjalanan kebangsaan dan kenegaraan Indonesia.

Namun, tidak semua warga NU memiliki pandangan yang sejalan dengan para pendiri PKB. Beberapa ulama mengritik karakter PKB yang terlalu berorientasi kebangsaan dan tidak secara tegas meneruskan tradisi politik Partai NU. Hal ini mengisyaratkan bahwa sikap politik warga NU tidak monolit. Mereka memiliki pemahaman yang beragam tentang bagaimana seharusnya tradisi politik NU ditransformasikan ke dalam praksis politik masa kini. Keragaman tadi telah mendorong munculnya beragam partai yang memiliki sejarah kekerabatan dengan NU (filogeni).

Filogeni politik PKB tidak didorong oleh perbedaan ideologis di antara empat partai yang lahir di kalangan NU. Perbedaan tadi hanya memperlihatkan "jalan yang berbeda menuju tujuan yang sama". Selain karena friksi yang terjadi di kalangan elit NU, kemunculan partai tersebut lebih disebabkan perbedaan penafsiran tentang bagaimana seharusnya sistem nilai yang dianut NU ditransformasikan ke dalam wilayah politik. Perbedaan tadi melemahkan barisan politik NU. Kekuatan NU terpecah ke dalam sekutu-sekutu kecil yang mudah digilas kekuatan lain.

Mabda Siyasiy memberikan gambaran jelas tentang hakikat PKB dan garis perjuangannya. Ideologi humanisme religius bukan hanya berakar pada fitrah manusia, tetapi juga mempertimbangkan taraf perkembangan manusia dalam konteks sosial. Paradigma humanisme berakar pada hakikat manusia yang suci, cenderung pada hal-hal yang baik, keunggulan indrawi dan memiliki akal. Sedangkan dimensi religius berkaitan dengan hidayah wahyu, pertolongan, dan petunjuk Allah swt. Artinya, selain menerima nilai-nilai yang diturunkan Allah swt, PKB pun menyerap nilainilai yang tumbuh dari perkembangan manusia.

Mengacu kepada sistem nilai yang terkandung di dalam Mabda Siyasiy jelas bahwa partai yang dikehendaki adalah partai yang terbuka. Meski naskah ini dirumuskan para tokoh NU, namun PKB tidak dimaksudkan sebagai reinkarnasi Partai NU. Berbeda dengan Partai NU yang pada awalnya mencita-citakan terwujudnya syari'at Islam dalam tatanan kenegaraan, PKB tidak mengusung formalisme Islam. Bagi PKB, mengambil sari pati nilai-nilai Islam untuk diangkat ke dalam hukum positiflebih diutamakan daripada menjadikan syari'at Islam sebagai dasar negara.

Kiai menjadi simbol signifikan dalam 
komunikasi politik PKB. Di antara para kiai, Abdurrahman Wahid masih menjadi primus inter pares. Figuritas Gus Dur bukan hanya dibentuk oleh keunggulan dari segi nasab, tetapi juga didukung oleh keluasan pengetahuan, paham pluralitasnya, dan sensitivitas terhadap budaya lokal. Pemerintahan Wahid yang hanya 21 bulan menjadi eksperimen implementasi platform pluralitas PKB.

Demokrasi dan penguatan masyarakat sipil (civil society) menjadi kredo (paham) pemerintahan Abdurrahman Wahid. Hal ini terlihat dari wacana dan langkah-langkah politik yang diambil Abdurrahman Wahid dalam 21 bulan kepemimpinannya.

Ide membangun kemandirian masyarakat sehingga tidak bergantung sepenuhnya kepada negara (otonomi relatif warga negara) menjadi gagasan besar Abdurrahman Wahid. Gagasan tadi diterjemahkan ke dalam wacana (kesatuan tutur) supremasi sipil, kemerdekaan pers dan kebebasan berbicara, pembelaan hak minoritas, penguatan posisi masyarakat di hadapan negara, supremasi hukum, dan deformalisasi Islam.

Selain mengembangkan wacana di atas, Abdurrahman Wahid pun melakukan "ijtihad" dalam hal hubungan penguasa dan rakyatnya. Kepala negara yang sebelumnya "sulit disentuh", dicitrakan sebagai terbuka dan dekat dengan rakyat. Hal ini paling tidak terlihat dari tindakannya melakukan desakralisasi istana dan memajukan informalitas komunikasi politik.

\section{Identifikasi Kepartaian}

Terlepas dari perolehan suara PKB yang masih kecil, langkah-langkah yang ditempuh kader PKB NTT memperlihatkan fenomena menarik. Fenomena tadi dalam beberapa hal mirip langkahlangkah yang ditempuh pengurus PKB di Jawa dengan spektrum yang berbeda.

Pertama, seperti halnya di Jawa, di NTT figur Gus Dur menjadi faktor penentu. Bukan platform yang memikat mereka. Figur Gus Dur yang dinilai mampu memberi keteduhan bagi warga Kristiani menawan mereka.
Kedua, seperti halnya di Jawa, identifikasi kepartaian belum terbentuk. Pemanfaatan struktur keagamaan Kristen sebagai strategi perluasan dukungan mendekati pola rekrutmen di Jawa yang memanfaatkan jaringan pesantren. Dengan kata lain, baik di Jawa maupun di NTT yang terjadi adalah transformasi kesetian primordial ke wilayah politik.

Ketiga, pemanfaatan pranata budaya sebagai media komunikasi politik. Ke dalamnya termasuk melakukan politik kultural dengan memanfaatkan opinion leaders, baik dalam wilayah adat maupun agama. Hal ini dimungkinkan karena masyarakat NTT terstruktur secara hierarkhis dengan raja dan kepala suku sebagai patronnya. Realitas terakhir, lagi-lagi, memiliki kemiripan dengan struktur masyarakat Jawa yang sentris, meski yang menjadi patron bukan kepala suku.

Keempat, selain menarik simpati masyarakat yang terlanjur jatuh hati pada Partai Golkar dan PDIP (orientasi merah-kuning) tantangan yang dihadapi kader PKB NTT adalah pencitraan. Citra PKB sebagai partai Islam melekat cukup kuat di benak masyarakat NTT. Citra seperti ini tidak menunjang pemasaran politik PKB. Karena itu, langkah yang ditempuh adalah mengarusutamakan citra PKB sebagai partai terbuka, nasionalis, dan demokratis. Namun dalam praktiknya, strategi tadi berbentuk deislamisasi, yakni mengurangi simbolsimbol keislaman.

Fenomena terakhir, berbeda kontras dengan realitas PKB di Jawa, khususnya Tapal Kuda. Namun, keduanya menemukan titik temu, yakni isu agama dan primordial menjadi "kartu" yang menentukan. Inilah dilema PKB dalam membangun demokrasi. Membangun demokrasi tidak bisa berlandaskan primordialisme, sebab nalar demokrasi menuntut egalitarianisme, transparansi, dan tanpa diskriminasi dalam semua bidang.

\section{Pola Komunikasi Politik Kiai}

Meskipun PKB bersifat terbuka dan dihuni oleh orang-orang dengan latar belakang budaya yang beragam, namun kultur NU tetap dominan. Dalam berbagai acara yang digelar PKB, baik di 
pusat maupun di daerah, kultur dan simbol NU masih menjadi mainstream (arus utama). Pembacaan shalawat dalam acara-acara yang digelar PKB adalah indikasi penetrasi kultur NU terhadap budaya komunikasi PKB.

Budaya NU menjadi rujukan reproduksi simbol-simbol PKB. Simbol-simbol PKB adalah modifikasi simbol-simbol NU yang ditransformasikan ke dalam lingkungan yang lebih luas. Proses transformatif tadi dapat dilukiskan dalam gambar berikut.

Kiai menjadi nucleus (unsur inti) komunitas pesantren dan NU. Pada gilirannya, ketiga unsur ini menjadi sumber dan rujukan dalam proses reproduksi simbol-simbol PKB. Dengan kata lain, simbol PKB adalah simbol-simbol NU yang telah mengalami metamorfosis. Di dalam proses ini, kiai yang berorientasi politik (political-oriented kiai) menjadi agen yang mempersambungkan prosesproses transformatif tadi.

Introduksi cara-cara modern (modernisasi) yang melanda warga NU - seperti yang ditandai oleh kahadiran struktur modern - belum mengubah pola-pola relasi yang sudah ada. Bahkan, ikatan terhadap faktor-faktor primordial menguat sejalan dengan pelekatan diri mereka terhadap struktur formal yang mereka ciptakan. Fenomena inilah yang menimbulkan kecenderungan munculnya etnisitas dalam politik (political ethnicity).

Modernisasi yang dijalani PKB tidak ditempuh dengan cara mengikis pola hubungan yang sudah ada, melainkan hanya memfungsikan kembali struktur-struktur tradisional yang sudah diwarisi. Faktor nasab, etnis, dan usia, masih menjadi unsur primer dalam alokasi kekuasaan. Diferensiasi antara wilayah politik dan religius hampir tidak terjadi. Hal ini dimungkinkan karena teologi sosial politik yang dianut amat fleksibel dalam menghadapi perubahan-perubahan yang muncul akibat politik modernisasi yang ditempuh PKB.

Sebagai pengorganisasian kultur NU secara politik, PKB mewarisi kerangka berpikir khas NU, yang tidak lain adalah organisasi sosial keagamaan (jam'iyyah ijtima'iyyah diniyyah). Kerangka berpikir tadi tampak dalam ciri-ciri primer NUdan dalam kiprah politiknya. Ciri-ciri primer tadi ditransformasikan ke dalam praksis politik PKB sehingga menjadi basis identifikasi kepartaian, terutama di daerah-daerah yang dikenal basis NU. Namun, sebagai partai politik yang dimaksudkan sebagai alat transformasi sosial politik NU, PKB dituntut memiliki sensitivitas terhadap nilai sosial politik yang relevan dengan kaidah-kaidah yang dianut NU.

Secara normatif, kerangka berpikir tadi ditemukan di dalam dokumen-dokumen historis PKB, tempat di mana ideologi politik PKB dituangkan. Preferensi tentang masyarakat dan negara yang dicita-citakan PKB bukan hanya berbasis pada etika dan nilai-nilai keagamaan, tetapi juga tidak sekuler - dalam arti memisahkan kehidupan bernegara dari kehidupan beragama meski sejak awal PKB tidak menghendaki formalisasi Islam.

Dilihat dari konteks di atas, sifat terbuka yang dianut PKB berkonotasi sebagai quasi terbuka, atau dalam bahasa para kiai di Jawa Timur sebagai "terbuka yang tertutup". Keterbukaan PKB berlaku sampai pada titik tidak mengganggu sistem nilai yang dianut NU. Sederhananya, PKB bersifat tertutup terhadap anasir-anasir yang merusak kaidah dasar yang dianut warga NU.

Dengan kata lain, quasi terbuka bermakna PKB itu inklusif sekaligus ekslusif. Inklusif dalam hal muamalah dan interaksi sosial, tetapi eksklusif dalam hal ibadah dan akidah. Kaidah ini bermakna bahwa PKB dapat menggelar kegiatan muamalah dan interaksi sosial tanpa membedakan agama dan latar belakang sosial budaya. Namun, PKB harus membatasi diri pada hal-hal yang menyangkut ibadah dan akidah.

Dalam hubungannya dengan anasir-anasir agama yang membentuk konfigurasi dukungan bagi PKB, keterbukaan harus dipahami sebagai sikap toleran (tasamuh) terhadap agama mana pun tanpa meninggalkan keyakinan teologisnya sendiri. Di dalam wilayah ibadah dan akidah, PKB tidak memiliki otoritas untuk ikut campur, meski tidak akan pernah terlepas sama sekali.

Karena itu, platform pluralitas PKB menuntut manajemen komunikasi tersendiri dalam proses 
sosialisasinya mengingat fakta bahwa PKB telah secara nyata membuka basis dukungan di kalangan non NU, bahkan non-Islam. Manajemen komunikasi PKB perlu dirancang paling tidak untuk dua kebutuhan.

Pertama, memelihara dukungan pemilih dari kalangan Muslim yang menjadi captive market, sekaligus menarik dukungan non-Muslim lewat penampilan sosok partai yang moderat. Sebelum menarik kelompok kedua, PKB harus mempertahankan dukungan kelompok pertama dengan meyakinkan bahwa format "Islam Kebangsaan" yang dianut NU dan diwarisi PKB adalah salah satu bentuk jawaban dalam mengatasi berbagai persoalan, khususnya dalam masalah relasi agama dan negara.

Sosok partai yang moderat menjadi daya tarik PKB di kalangan non-Muslim, paling tidak di Nusa Tenggara Timur. Beberapa pemilih PKB di kota Kupang mengaku tertarik pada PKB karena mampu memberi kesejukan bagi warga Kristiani, yang dalam kehidupan nasional menjadi minoritas. Sayangnya, eksperimen PKB menarik dukungan non-Muslim tidak dapat meningkatkan raihan suara PKB secara signifikan dalam Pemilu 2004. Bahkan, secara nasional raihan suara PKB menurun bila dibandingkan Pemilu 1999.

Kedua, menggeser kekuatan PKB dari anasiranasir yang bersifat primordial ke arah keunggulan kompetitifyang berlandaskan kultur, program, dan kepemimpinan. Namun, transformasi nilai tadi tidak bisa dilakukan secepat membalikkan telapak tangan karena ia menyangkut atribut sosial yang telah terlanjur dianggap sebagai pandangan hidup (ways of life).

Dikaji dari perspektif tadi, sosialisasi platform pluralitas PKB bertolak dari keyakinan bahwa akidah dan ritus ibadah setiap agama adalah hak ekslusif setiap pemeluknya. Wilayah ini merupakan area privat, yang tidak menjadi otoritas PKB untuk merekayasanya. Sosialisasi platform pluralitas PKB tidak menjangkau wilayah akidah dan ibadah, meskipun senantiasa mendapatkan penetrasi, bahkan dengan sengaja menyerap, nilai agama yang ditransformasikan ke dalam gelanggang politik.
Dengan demikian, medan khidmat sosialisasi platform pluralitas PKB adalah wilayah muamalah dan interaksi sosial, yakni seperangkat panduan sosial yang diturunkan dari nilai-nilai keagamaan dan berlaku universal. Mengacu kepada rumusan platform $\mathrm{PKB}$, nilai-nilai dasar dimaksud mencakup beberapa hal. Kesatu, jaminan penegakan HAM dan kejujuran besumber hati nurani (as-shidqu). Kedua, mengembangkan sikap dapat dipercaya, setia dan tepat janji. Ketiga, menciptakan tatanan masyarakat yang mampu memecahkan masalah sosial (al-amanah wa al-wafau bi al-ahdli), adil (al-'adalah), tolong-menolong (al-ta'awun), konsisten (al-istiqamah), musyawarah (al-syura), dan kesamaan kedudukan di muka hukum (almusawa).

Fakta bahwa tidak semua orang yang mengidentifikasikan dirinya dengan NU memilih PKB menunjukkan bahwa keputusan untuk memilih tidak semata-mata ditentukan oleh kekuatankekuatan dari luar. Demikian pula fakta bahwa sejumlah non-Muslim yang memutuskan memilih PKB menunjukkan bahwa tindakan politik mereka tidak tunduk pada pencitraan yang mengesankan PKB sebagai partai orang Islam. Kedua fakta ini mengisyaratkan bahwa tindakan politik warga PKB melibatkan proses interpretatif atas simbol-simbol yang dipertukarkan ketika proses komunikasi politik berlangsung.

Dikaji dari perspektif interaksi simbolik, sosialisasi platform pluralitas PKB akan bergantung kepada kualitas hubungan dan kelangsungan interaksi, di mana kedua pihak (aktivis, politisi, dan komunikator profesional versus khalayak, simpatisan, dan konstituen PKB) saling menukar makna dan kelakuan. Sebuah transaksi politik yang di dalamnya melibatkan proses penciptaan kesan melalui proses impression management (Goffman, 1959: 203).

Penataan kesan menjadi kunci keberhasilan politisi dalam serangkaian proses transasksi politik, karena sejak lama diyakini bahwa banyak aspek politik berupa penampilan (appearance). Para politikus beraksi di depan publik sedemikian rupa, sehingga mereka menganggapnya sebagai orang penting, pintar, dan layak dipercaya untuk 
mengemban amanah. Para pemimpin dan aktivis partai politik harus memainkan peran seperti yang dibayangkan khalayak. Mereka akan selalu menemukan banyak orang yang siap "dikelabui". Mereka menjanjikan sesuatu, sehingga mereka dikesani sebagai sosok yang merasakan sesuatu serta berpikir dan bertindak menurut apa yang dibayangkan konstituennya.

\section{Kesimpulan}

Pertumbuhan politik kepartaian di Indonesia tidak identik dengan sekularisasi, melainkan transformasi kesadaran religius ke dalam wilayah politik. Keyakinan bahwa urusan politik dapat diatur dan ditentukan oleh kehendak manusia sendiri tidak menafikan hak prerogatif Tuhan dalam keseluruhan proses tersebut.

Komunikasi internal dan esksternal yang tidak efektif menyebabkan substansi platform tidak tersosialisasikan dengan baik. Akibatnya keberadaan platform menjadi tidak fungsional. Platform menjadi atribut yang menunjang penampilan politisi dalam panggung depan. Kedudukan platform tergantikan oleh figur yang menjadi ikon (icon) sekaligus ruh partai. Kondisi ini melahirkan pola komunikasi politik yang melekatkan kredibilitas komunikator pada faktor-faktor yang diwariskan (askriptif) dan menempatkan figur sebagai mesiah. Pola ini mengukuhkan budaya konteks tinggi (high contex) yang ditandai oleh penggunaan kode terbatas (restricted codes). Spektrum komunikasi internal dan eksternal partai yang tidak egaliter bukan hanya menjadikan klaim inklusivitas sebagai keterbukaan semu (quasi terbuka), tetapi juga mempertajam segregasi antarfaksi, sehingga partai menjadi mudah terfragmentasi ke dalam kekuatan sempalan.

Penguasaan sumber daya komunikasi partai politik yang terpusat di tangan figur melahirkan kepemimpinan partai yang mesianik. Pola ini bukan hanya melekatkan otoritas kepemimpinan pada tradisi dan kharisma sebagaimana lazim dianut selama ini, tetapi juga menempatkan figur sebagai mesiah (ratu adil) yang tidak pernah berbuat salah.
Kepemimpinan mesianik dikukuhkan oleh pola orientasi pengikut yang bercorak parokhial dan rekrutmen yang berdasar kepada nasab sehingga kelahiran dan perkawinan menjadi alat promosi karier yang penting. Sedemikian pentingnya peran politik keluarga-penguasa, maka perhatian para pencari kekuasaan tertuju pada pola kekuasaan keluarga sebagai miniatur pola kekuasaan partai. Partai sulit memainkan perannya sebagai representasi kepentingan pengikut, melainkan hanya mengukuhkan dominasi kaukus yang dibentuk tokoh-tokoh senior partai (gerontocracy). Kecenderungan ini mengukuhkan keberlakuan hukum besi oligarkhi, dimana aristokrat tradisional berperan sebagai oligoi-oligoi yang mengendalikan partai.

Pola komunikasi politik yang askriptif dan kepemimpinan mesianik menyebabkan tidak terbangunnya wacana kritis di kalangan fungsionaris dan simpatisan partai. Identifikasi kepartaian tidak terbangun atas penguasaan nilai dasar dan cita-cita partai, melainkan merupakan bentuk transformasi kesetiaan primordial ke dalam praksis politik. Involusi politik ini dikukuhkan oleh pola sosialisasi yang menempatkan kepatuhan di atas pertimbangan rasional. Manipulasi simbolsimbol agama dan budaya menjadi unsur primer dalam komunikasi antara pemimpin dengan pengikut sekaligus menjadi alat dominasi dan mobilisasi dukungan yang penting. Pola komunikasi tadi ditandai oleh pemakaian alat-alat retorika (baik verbal maupun nonverbal) yang bersumber dari - atau adaptasi bentuk ritual - agama dan budaya sehingga pemaknaan atas simbolsimbol tersebut bersifat isoterik sesuai dengan pengalaman religio-politik penggunanya.

Proses tersebut bukan hanya memberi peluang terjadinya kesalahpahaman, tetapi juga menguatkan kecenderungan menjadikan agama dan budaya sebagai alat justifikasi keputusan dan tindakan politik. Prinsip "ekonomi pernyataan" bukan hanya dapat mengurangi risiko keterpurukan citra akibat kesalahan manajemen komunikasi, tetapi juga dapat menambah daya persuasi komunikasi politik. 


\section{Daftar Pustaka}

Alwasilah, A. Chaedar. 2002. Pokoknya Kualitatif: Dasar-dasar Merancang dan Melakukan Penelitian Kualitatif. Jakarta: Pustaka Jaya.

Combs, James E \& Dan Nimmo 1981. A Primer of Politics. New York: Macmillan Publishing Company.

Creswell, John W. 1994. Research Design: Qualitative \& Quantitative Approaches. California: SAGE Publications.

1998. Qualitative Inquiry and Research Design: Choosing Among Five Traditions. California: SAGE Publications.

Feith, Herbert. 1962. The Decline of Constitutional Democracy in Indonesia. New York: Cornell University Press.

Feith, Herbert \& Lance Castles. 1970. Indonesian Political Thinking 1945-1965. USA: Cornell University.

Geertz, Clifford. 1981. Abangan, Santri, Priyayi dalam Masyarakat Jawa. Jakarta: Pustaka Jaya.

1992. Kebudayaan \& Agama, terjemahan Francisco Budi Hardiman. Yogyakarta: Kanisius.
1963. Old Societies and New States: The Quest for Modernity in Asia and Africa, The Free Press of Glencoe.

Goffman, Erving. 1974. The Presentation of Self ini Everyday Life. USA: Penguin Books.

Lewellen, Ted C. 1982. Political Anthropology, Berger L. Carey Publisher.

Martindale, Don. 1960. The Nature and Types of Sociological Theory, Cambridge, Massachusetts, The Riverside Press.

Mulyana, Deddy. 2001. Metode Penelitian Kualitatif: Paradigma Baru Ilmu Komunikasi dan Ilmu Sosial Lainnya. Bandung: Remaja Rosdakarya.

Nimmo, Dan D. dan Keith R. Sanders. 1981. Handbook of Political Communication. California: Sage Publication, Inc.

1978. Political Communication and Public Opinion in America. California: Goodyear Publishing Company.

Sherman, Arnolk K, dan Aliza Kolker. 1987. The Social Bases of Politics. Belmont: Wardworth Publishing Company, 


\title{
Transformasi Loyalitas Primordial sebagai Basis Identifikasi Kepartaian: Kasus Partai Kebangkitan Bangsa dalam Pemilihan Umum 1999 dan 2004
}

\author{
Karim Suryadi
}

ABSTRACT

\begin{abstract}
Transformation of primordial loyalty into the political sphere rather than understanding of the substance of the party's platform is a key factor for PKB's (National Awakening Party) devotees to adhere to the party. The platform has not been effectively socialized. The practice of the party has not been believed as a requisite condition to create an order society. On the other hand, adhering to Nahdlatul Ulama (NU) and inclining to submit to orders or wishes of Kiai (Muslim Scholars) is believed among PKB's voters as a means by which a good community is created (khoerul barriyah). Therefore, since the 2004 General Election,

Kiai's political communication and orientations have become the partisans' primary roles among $P K B$ 's constituents.
\end{abstract}

Kata kunci: "platform", identitas partai, komunikasi politik kiai, partisan, loyalitas primordial

\section{Pendahuluan}

Kemunculan Partai Kebangkitan Bangsa (PKB) dalam pusaran arus politik partai pasca Orde Baru menarik dikaji karena dua alasan berikut. Pertama, keterlibatan Pengurus Besar Nahdlatul Ulama (PBNU) dalam membidani kelahiran PKB mengisyaratkan keseriusannya dalam mengarahkan suara warga Nahdlatul Ulama (NU). Lebih dari sekadar merestui, keterlibatan PBNU dapat dibaca sebagai kesungguhan dalam melahirkan sang "putra mahkota". Padahal, aspirasi politik nahdliyin tidak benar-benar monolit. Partai politik yang lahir dari rahim NU bukan hanya PKB. Hal ini memunculkan dugaan adanya kesadaran yang mempersatukan dan mendesak warga NU untuk sementara - hanya akan berkhidmat pada PKB.
Kedua, dibanding partai baru lainnya, $\mathrm{PKB}$ adalah peraih suara terbanyak pada Pemilu 1999. Perolehan suara PKB mendekati raihan suara Partai NU pada Pemilu 1955. Jumlah ini melampaui raihan suara Partai Persatuan Pembangunan (PPP), yang sudah hadir sejak Orde Baru dan merupakan hasil fusi NU dengan Partai Muslimin Indonesia (Parmusi), Partai Syarikat Islam Indonesia (PSII), dan Persatuan Tarbiyah Indonesia (Perti), pada 5 Januari 1973.

Kembalinya NU ke kancah politik menarik dikaji, karena sejak 1984 NU memutuskan kembali ke khittah 1926. Keputusan ini bukan hanya mengharuskan NU menanggalkan atribut partai, tetapi juga menegaskan kembali jati dirinya sebagai organisasi sosial keagamaan (jam'iyyah diniyah). Fenomena ini memunculkan pertanyaan, faktor apa 
yang membuat dukungan terhadap PKB yang dianggap sebagai "titisan" Partai NU ini relatif stabil, padahal deideologisasi yang dijalankan Orde Baru berlangsung sangat intensif?

\section{Metode Penelitian}

Kemunculan PKB sebagai pemenang ketiga di bawah Partai Demokrasi Indonesia Perjuangan (PDIP) dan Partai Golongan Karya (Golkar), atau terbesar dibandingkan seluruh partai yang muncul pasca-Orde Baru, mengisyaratkan adanya gejala "reinkarnasi" politik NU yang tidak sempurna. Dugaan ini muncul karena kelahiran PKB dibidani NU, sehingga PKB menjadi anak emas NU. Namun, perolehan suara PKB yang jauh di bawah jumlah pemilih yang diasumsikan berhaluan NU menyiratkan dukungan warga NU terhadap PKB tidak bulat.

Selain menguatnya isu primordial, kemunculan partai politik menjelang Pemilu 1999 ditandai absennya platform yang dapat menggugah partisipasi publik. Fenomena ini memunculkan dugaan bahwa keputusan yang diambil pemilih saat memberikan suara dan loyalitas yang terbangun di kalangan para anggota lebih didasarkan atas pertimbangan di luar pemahaman mereka tentang platform partai.

Penelitian ini menggunakan metode studi kasus sebagai salah satu tradisi kualitatif(Creswell, 1998: 63) dengan pendekatan proses (Combs, 1981: 39-66). Proses sosialisasi platform pluralitas Partai Kebangkitan Bangsa (PKB) dan komunikasi politik kiai dalam membentuk identifikasi kepartaian dijadikan kasus dalam penelitian ini.

Data primer dalam penelitian ini dikumpulkan melalui wawancara terhadap 16 informan kunci dan beberapa kelompok informan yang digali dalam bentuk diskusi (focus group discussion). Untuk menghindari "bias partai", informasi dikumpulkan pula dari politisi NU yang berkiprah di luar PKB, seperti di PPP, Golkar, Partai Bintang Reformasi, dan PAN.

Informan ditentukan secara snowball, sehingga lokasi penelitian bergantung kepada di mana informan berada atau peristiwa politik yang digelar PKB berlangsung. Bandung, Jakarta, Cirebon, Sukabumi, Sampang, Pasuruan, dan Surabaya, sebagai daerah yang dikenal sebagai basis PKB menjadi daerah penelitian yang utama, serta Nusa Tenggara Timur (NTT), sebagai daerah percontohan pengembangan wawasan kebangsaan ala PKB.

Selain digali melalui wawancara mendalam, data primer dihimpun melalui pengamatan terlibat terhadap sejumlah objek dan peristiwa. Untuk kepentingan penelitian ini, telah dilakukan pengamatan dan wawancara dengan para pelaku yang terlibat dalam perumusan calon anggota legislatif dan kampanye menjelang Pemilu 2004. Berbagai forum yang bertujuan mematangkan calon presiden yang akan dimajukan PKB dan kampanye pemilihan presiden menjadi peristiwa yang penting.

Sementara, data sekunder dihimpun dari informasi kepustakaan, baik dari buku teks, jurnal ilmiah, hasil penelitian, laporan, dan dokumen; baik yang diterbitkan untuk umum maupun dokumen yang diterbitkan untuk kalangan internal PKB. Keseluruhan hasil penelitian kepustakaan menjadi sumber data yang penting bagi penelusuran polapola partisipasi dan komunikasi politik NU. Penelusuran data dokumenter difokuskan kepada keterlibatan ulama/kiai dalam wilayah politik serta akar-akar tradisi yang menjadi rujukan penyusunan platform.

Keseluruhan data dihimpun mulai September 2003 hingga Juni 2005. Data final yang dianalisis dan disajikan adalah data yang telah diseleksi melalui member checking.

\section{Genesis "Platform" dan Filogeni Politik PKB}

Bila dilihat dari kulturnya, PKB bukan entitas yang benar-benar baru. PKB hanya mewadahi sesuatu yang sudah ada, yakni komunitas NU dengan segenap sistem nilai yang dianutnya. Meskipun tidak terdapat hubungan organisatoris antara NU dan PKB, namun di antara keduanya sulit dipisahkan. PKB memang bukan organisasi yang dibentuk dengan tugas melaksanakan pro- 
gram-program NU, namun secara embrional PKB dan NU dihubungkan oleh "plasenta" yang sulit diputus.

Keterlibatan PBNU dalam membidani kelahiran PKB sampai pada derajat dituduh melanggar Khittah 1926, mengimplikasikan hal-hal berikut. Pertama, hasrat politik NU tidak padam karena langkah penarikan diri dari wilayah politik praktis. Hasrat berpolitik warga nahdliyin pun tidak tergerus deideologisasi yang diterapkan rezim Orde Baru. Bahkan langkah ini terbukti menjadi titik tolak ploriferasi politik NU.

Kedua, keputusan NU memfasilitasi pembentukan PKB merupakan bentuk adaptabilitas sikap politik NU. Fleksibilitas sikap politik NU terlihat di sepanjang sejarah pertumbuhan NU. Baik sebagai organisasi kemasyarakatan (jam'iyyah diniyah) maupun sebagai partai politik, sikap politik NU terkenal lentur. Meskipun dalam kasus tertentu NU tampil radikal (seperti menolak Perjanjian "Linggarjati" dan "Renville" atau ketika menolak Mutual Secutity Act dan dewan keamanan bersama yang pro AS pada 1952), namun watak akomodatif lebih mewarnai sikap politik NU.

Keterbukaan yang digagas para pendiri PKB dilandasi pandangan bahwa corak partai politik masa depan adalah lintas etnis, jauh melampaui keanggotaan sebuah organisasi kemasyarakatan. Pandangan ini menempatkan Pancasila sebagai asas partai, sekaligus menempatkan Islam sebagai akhlak masyarakat (etika sosial), dan sumber materi perundangan.

Beberapa dasar pertimbangan menyangkut pemilihan nama partai mengisyaratkan bahwa secara kultur PKB mengadopsi sikap kemasyarakatan yang dikembangkan NU. Kultur PKB adalah kultur NU, karena PKB adalah pengorganisasian kultur NU secara politik. Kultur Islam ahlussunnah wal Jama'ah menjadi basis historis dan ideologis PKB, yang bersenyawa dengan sejarah perjalanan kebangsaan dan kenegaraan Indonesia.

Namun, tidak semua warga NU memiliki pandangan yang sejalan dengan para pendiri PKB. Beberapa ulama mengritik karakter PKB yang terlalu berorientasi kebangsaan dan tidak secara tegas meneruskan tradisi politik Partai NU. Hal ini mengisyaratkan bahwa sikap politik warga NU tidak monolit. Mereka memiliki pemahaman yang beragam tentang bagaimana seharusnya tradisi politik NU ditransformasikan ke dalam praksis politik masa kini. Keragaman tadi telah mendorong munculnya beragam partai yang memiliki sejarah kekerabatan dengan NU (filogeni).

Filogeni politik PKB tidak didorong oleh perbedaan ideologis di antara empat partai yang lahir di kalangan NU. Perbedaan tadi hanya memperlihatkan "jalan yang berbeda menuju tujuan yang sama". Selain karena friksi yang terjadi di kalangan elit NU, kemunculan partai tersebut lebih disebabkan perbedaan penafsiran tentang bagaimana seharusnya sistem nilai yang dianut NU ditransformasikan ke dalam wilayah politik. Perbedaan tadi melemahkan barisan politik NU. Kekuatan NU terpecah ke dalam sekutu-sekutu kecil yang mudah digilas kekuatan lain.

Mabda Siyasiy memberikan gambaran jelas tentang hakikat PKB dan garis perjuangannya. Ideologi humanisme religius bukan hanya berakar pada fitrah manusia, tetapi juga mempertimbangkan taraf perkembangan manusia dalam konteks sosial. Paradigma humanisme berakar pada hakikat manusia yang suci, cenderung pada hal-hal yang baik, keunggulan indrawi dan memiliki akal. Sedangkan dimensi religius berkaitan dengan hidayah wahyu, pertolongan, dan petunjuk Allah swt. Artinya, selain menerima nilai-nilai yang diturunkan Allah swt, PKB pun menyerap nilainilai yang tumbuh dari perkembangan manusia.

Mengacu kepada sistem nilai yang terkandung di dalam Mabda Siyasiy jelas bahwa partai yang dikehendaki adalah partai yang terbuka. Meski naskah ini dirumuskan para tokoh NU, namun PKB tidak dimaksudkan sebagai reinkarnasi Partai NU. Berbeda dengan Partai NU yang pada awalnya mencita-citakan terwujudnya syari'at Islam dalam tatanan kenegaraan, PKB tidak mengusung formalisme Islam. Bagi PKB, mengambil sari pati nilai-nilai Islam untuk diangkat ke dalam hukum positiflebih diutamakan daripada menjadikan syari'at Islam sebagai dasar negara.

Kiai menjadi simbol signifikan dalam 
komunikasi politik PKB. Di antara para kiai, Abdurrahman Wahid masih menjadi primus inter pares. Figuritas Gus Dur bukan hanya dibentuk oleh keunggulan dari segi nasab, tetapi juga didukung oleh keluasan pengetahuan, paham pluralitasnya, dan sensitivitas terhadap budaya lokal. Pemerintahan Wahid yang hanya 21 bulan menjadi eksperimen implementasi platform pluralitas PKB.

Demokrasi dan penguatan masyarakat sipil (civil society) menjadi kredo (paham) pemerintahan Abdurrahman Wahid. Hal ini terlihat dari wacana dan langkah-langkah politik yang diambil Abdurrahman Wahid dalam 21 bulan kepemimpinannya.

Ide membangun kemandirian masyarakat sehingga tidak bergantung sepenuhnya kepada negara (otonomi relatif warga negara) menjadi gagasan besar Abdurrahman Wahid. Gagasan tadi diterjemahkan ke dalam wacana (kesatuan tutur) supremasi sipil, kemerdekaan pers dan kebebasan berbicara, pembelaan hak minoritas, penguatan posisi masyarakat di hadapan negara, supremasi hukum, dan deformalisasi Islam.

Selain mengembangkan wacana di atas, Abdurrahman Wahid pun melakukan "ijtihad" dalam hal hubungan penguasa dan rakyatnya. Kepala negara yang sebelumnya "sulit disentuh", dicitrakan sebagai terbuka dan dekat dengan rakyat. Hal ini paling tidak terlihat dari tindakannya melakukan desakralisasi istana dan memajukan informalitas komunikasi politik.

\section{Identifikasi Kepartaian}

Terlepas dari perolehan suara PKB yang masih kecil, langkah-langkah yang ditempuh kader PKB NTT memperlihatkan fenomena menarik. Fenomena tadi dalam beberapa hal mirip langkahlangkah yang ditempuh pengurus PKB di Jawa dengan spektrum yang berbeda.

Pertama, seperti halnya di Jawa, di NTT figur Gus Dur menjadi faktor penentu. Bukan platform yang memikat mereka. Figur Gus Dur yang dinilai mampu memberi keteduhan bagi warga Kristiani menawan mereka.
Kedua, seperti halnya di Jawa, identifikasi kepartaian belum terbentuk. Pemanfaatan struktur keagamaan Kristen sebagai strategi perluasan dukungan mendekati pola rekrutmen di Jawa yang memanfaatkan jaringan pesantren. Dengan kata lain, baik di Jawa maupun di NTT yang terjadi adalah transformasi kesetian primordial ke wilayah politik.

Ketiga, pemanfaatan pranata budaya sebagai media komunikasi politik. Ke dalamnya termasuk melakukan politik kultural dengan memanfaatkan opinion leaders, baik dalam wilayah adat maupun agama. Hal ini dimungkinkan karena masyarakat NTT terstruktur secara hierarkhis dengan raja dan kepala suku sebagai patronnya. Realitas terakhir, lagi-lagi, memiliki kemiripan dengan struktur masyarakat Jawa yang sentris, meski yang menjadi patron bukan kepala suku.

Keempat, selain menarik simpati masyarakat yang terlanjur jatuh hati pada Partai Golkar dan PDIP (orientasi merah-kuning) tantangan yang dihadapi kader PKB NTT adalah pencitraan. Citra PKB sebagai partai Islam melekat cukup kuat di benak masyarakat NTT. Citra seperti ini tidak menunjang pemasaran politik PKB. Karena itu, langkah yang ditempuh adalah mengarusutamakan citra PKB sebagai partai terbuka, nasionalis, dan demokratis. Namun dalam praktiknya, strategi tadi berbentuk deislamisasi, yakni mengurangi simbolsimbol keislaman.

Fenomena terakhir, berbeda kontras dengan realitas PKB di Jawa, khususnya Tapal Kuda. Namun, keduanya menemukan titik temu, yakni isu agama dan primordial menjadi "kartu" yang menentukan. Inilah dilema PKB dalam membangun demokrasi. Membangun demokrasi tidak bisa berlandaskan primordialisme, sebab nalar demokrasi menuntut egalitarianisme, transparansi, dan tanpa diskriminasi dalam semua bidang.

\section{Pola Komunikasi Politik Kiai}

Meskipun PKB bersifat terbuka dan dihuni oleh orang-orang dengan latar belakang budaya yang beragam, namun kultur NU tetap dominan. Dalam berbagai acara yang digelar PKB, baik di 
pusat maupun di daerah, kultur dan simbol NU masih menjadi mainstream (arus utama). Pembacaan shalawat dalam acara-acara yang digelar PKB adalah indikasi penetrasi kultur NU terhadap budaya komunikasi PKB.

Budaya NU menjadi rujukan reproduksi simbol-simbol PKB. Simbol-simbol PKB adalah modifikasi simbol-simbol NU yang ditransformasikan ke dalam lingkungan yang lebih luas. Proses transformatif tadi dapat dilukiskan dalam gambar berikut.

Kiai menjadi nucleus (unsur inti) komunitas pesantren dan NU. Pada gilirannya, ketiga unsur ini menjadi sumber dan rujukan dalam proses reproduksi simbol-simbol PKB. Dengan kata lain, simbol PKB adalah simbol-simbol NU yang telah mengalami metamorfosis. Di dalam proses ini, kiai yang berorientasi politik (political-oriented kiai) menjadi agen yang mempersambungkan prosesproses transformatif tadi.

Introduksi cara-cara modern (modernisasi) yang melanda warga NU - seperti yang ditandai oleh kahadiran struktur modern - belum mengubah pola-pola relasi yang sudah ada. Bahkan, ikatan terhadap faktor-faktor primordial menguat sejalan dengan pelekatan diri mereka terhadap struktur formal yang mereka ciptakan. Fenomena inilah yang menimbulkan kecenderungan munculnya etnisitas dalam politik (political ethnicity).

Modernisasi yang dijalani PKB tidak ditempuh dengan cara mengikis pola hubungan yang sudah ada, melainkan hanya memfungsikan kembali struktur-struktur tradisional yang sudah diwarisi. Faktor nasab, etnis, dan usia, masih menjadi unsur primer dalam alokasi kekuasaan. Diferensiasi antara wilayah politik dan religius hampir tidak terjadi. Hal ini dimungkinkan karena teologi sosial politik yang dianut amat fleksibel dalam menghadapi perubahan-perubahan yang muncul akibat politik modernisasi yang ditempuh PKB.

Sebagai pengorganisasian kultur NU secara politik, PKB mewarisi kerangka berpikir khas NU, yang tidak lain adalah organisasi sosial keagamaan (jam'iyyah ijtima'iyyah diniyyah). Kerangka berpikir tadi tampak dalam ciri-ciri primer NUdan dalam kiprah politiknya. Ciri-ciri primer tadi ditransformasikan ke dalam praksis politik PKB sehingga menjadi basis identifikasi kepartaian, terutama di daerah-daerah yang dikenal basis NU. Namun, sebagai partai politik yang dimaksudkan sebagai alat transformasi sosial politik NU, PKB dituntut memiliki sensitivitas terhadap nilai sosial politik yang relevan dengan kaidah-kaidah yang dianut NU.

Secara normatif, kerangka berpikir tadi ditemukan di dalam dokumen-dokumen historis PKB, tempat di mana ideologi politik PKB dituangkan. Preferensi tentang masyarakat dan negara yang dicita-citakan PKB bukan hanya berbasis pada etika dan nilai-nilai keagamaan, tetapi juga tidak sekuler - dalam arti memisahkan kehidupan bernegara dari kehidupan beragama meski sejak awal PKB tidak menghendaki formalisasi Islam.

Dilihat dari konteks di atas, sifat terbuka yang dianut PKB berkonotasi sebagai quasi terbuka, atau dalam bahasa para kiai di Jawa Timur sebagai "terbuka yang tertutup". Keterbukaan PKB berlaku sampai pada titik tidak mengganggu sistem nilai yang dianut NU. Sederhananya, PKB bersifat tertutup terhadap anasir-anasir yang merusak kaidah dasar yang dianut warga NU.

Dengan kata lain, quasi terbuka bermakna PKB itu inklusif sekaligus ekslusif. Inklusif dalam hal muamalah dan interaksi sosial, tetapi eksklusif dalam hal ibadah dan akidah. Kaidah ini bermakna bahwa PKB dapat menggelar kegiatan muamalah dan interaksi sosial tanpa membedakan agama dan latar belakang sosial budaya. Namun, PKB harus membatasi diri pada hal-hal yang menyangkut ibadah dan akidah.

Dalam hubungannya dengan anasir-anasir agama yang membentuk konfigurasi dukungan bagi PKB, keterbukaan harus dipahami sebagai sikap toleran (tasamuh) terhadap agama mana pun tanpa meninggalkan keyakinan teologisnya sendiri. Di dalam wilayah ibadah dan akidah, PKB tidak memiliki otoritas untuk ikut campur, meski tidak akan pernah terlepas sama sekali.

Karena itu, platform pluralitas PKB menuntut manajemen komunikasi tersendiri dalam proses 
sosialisasinya mengingat fakta bahwa PKB telah secara nyata membuka basis dukungan di kalangan non NU, bahkan non-Islam. Manajemen komunikasi PKB perlu dirancang paling tidak untuk dua kebutuhan.

Pertama, memelihara dukungan pemilih dari kalangan Muslim yang menjadi captive market, sekaligus menarik dukungan non-Muslim lewat penampilan sosok partai yang moderat. Sebelum menarik kelompok kedua, PKB harus mempertahankan dukungan kelompok pertama dengan meyakinkan bahwa format "Islam Kebangsaan" yang dianut NU dan diwarisi PKB adalah salah satu bentuk jawaban dalam mengatasi berbagai persoalan, khususnya dalam masalah relasi agama dan negara.

Sosok partai yang moderat menjadi daya tarik PKB di kalangan non-Muslim, paling tidak di Nusa Tenggara Timur. Beberapa pemilih PKB di kota Kupang mengaku tertarik pada PKB karena mampu memberi kesejukan bagi warga Kristiani, yang dalam kehidupan nasional menjadi minoritas. Sayangnya, eksperimen PKB menarik dukungan non-Muslim tidak dapat meningkatkan raihan suara PKB secara signifikan dalam Pemilu 2004. Bahkan, secara nasional raihan suara PKB menurun bila dibandingkan Pemilu 1999.

Kedua, menggeser kekuatan PKB dari anasiranasir yang bersifat primordial ke arah keunggulan kompetitifyang berlandaskan kultur, program, dan kepemimpinan. Namun, transformasi nilai tadi tidak bisa dilakukan secepat membalikkan telapak tangan karena ia menyangkut atribut sosial yang telah terlanjur dianggap sebagai pandangan hidup (ways of life).

Dikaji dari perspektif tadi, sosialisasi platform pluralitas PKB bertolak dari keyakinan bahwa akidah dan ritus ibadah setiap agama adalah hak ekslusif setiap pemeluknya. Wilayah ini merupakan area privat, yang tidak menjadi otoritas PKB untuk merekayasanya. Sosialisasi platform pluralitas PKB tidak menjangkau wilayah akidah dan ibadah, meskipun senantiasa mendapatkan penetrasi, bahkan dengan sengaja menyerap, nilai agama yang ditransformasikan ke dalam gelanggang politik.
Dengan demikian, medan khidmat sosialisasi platform pluralitas PKB adalah wilayah muamalah dan interaksi sosial, yakni seperangkat panduan sosial yang diturunkan dari nilai-nilai keagamaan dan berlaku universal. Mengacu kepada rumusan platform $\mathrm{PKB}$, nilai-nilai dasar dimaksud mencakup beberapa hal. Kesatu, jaminan penegakan HAM dan kejujuran besumber hati nurani (as-shidqu). Kedua, mengembangkan sikap dapat dipercaya, setia dan tepat janji. Ketiga, menciptakan tatanan masyarakat yang mampu memecahkan masalah sosial (al-amanah wa al-wafau bi al-ahdli), adil (al-'adalah), tolong-menolong (al-ta'awun), konsisten (al-istiqamah), musyawarah (al-syura), dan kesamaan kedudukan di muka hukum (almusawa).

Fakta bahwa tidak semua orang yang mengidentifikasikan dirinya dengan NU memilih PKB menunjukkan bahwa keputusan untuk memilih tidak semata-mata ditentukan oleh kekuatankekuatan dari luar. Demikian pula fakta bahwa sejumlah non-Muslim yang memutuskan memilih PKB menunjukkan bahwa tindakan politik mereka tidak tunduk pada pencitraan yang mengesankan PKB sebagai partai orang Islam. Kedua fakta ini mengisyaratkan bahwa tindakan politik warga PKB melibatkan proses interpretatif atas simbol-simbol yang dipertukarkan ketika proses komunikasi politik berlangsung.

Dikaji dari perspektif interaksi simbolik, sosialisasi platform pluralitas PKB akan bergantung kepada kualitas hubungan dan kelangsungan interaksi, di mana kedua pihak (aktivis, politisi, dan komunikator profesional versus khalayak, simpatisan, dan konstituen PKB) saling menukar makna dan kelakuan. Sebuah transaksi politik yang di dalamnya melibatkan proses penciptaan kesan melalui proses impression management (Goffman, 1959: 203).

Penataan kesan menjadi kunci keberhasilan politisi dalam serangkaian proses transasksi politik, karena sejak lama diyakini bahwa banyak aspek politik berupa penampilan (appearance). Para politikus beraksi di depan publik sedemikian rupa, sehingga mereka menganggapnya sebagai orang penting, pintar, dan layak dipercaya untuk 
mengemban amanah. Para pemimpin dan aktivis partai politik harus memainkan peran seperti yang dibayangkan khalayak. Mereka akan selalu menemukan banyak orang yang siap "dikelabui". Mereka menjanjikan sesuatu, sehingga mereka dikesani sebagai sosok yang merasakan sesuatu serta berpikir dan bertindak menurut apa yang dibayangkan konstituennya.

\section{Kesimpulan}

Pertumbuhan politik kepartaian di Indonesia tidak identik dengan sekularisasi, melainkan transformasi kesadaran religius ke dalam wilayah politik. Keyakinan bahwa urusan politik dapat diatur dan ditentukan oleh kehendak manusia sendiri tidak menafikan hak prerogatif Tuhan dalam keseluruhan proses tersebut.

Komunikasi internal dan esksternal yang tidak efektif menyebabkan substansi platform tidak tersosialisasikan dengan baik. Akibatnya keberadaan platform menjadi tidak fungsional. Platform menjadi atribut yang menunjang penampilan politisi dalam panggung depan. Kedudukan platform tergantikan oleh figur yang menjadi ikon (icon) sekaligus ruh partai. Kondisi ini melahirkan pola komunikasi politik yang melekatkan kredibilitas komunikator pada faktor-faktor yang diwariskan (askriptif) dan menempatkan figur sebagai mesiah. Pola ini mengukuhkan budaya konteks tinggi (high contex) yang ditandai oleh penggunaan kode terbatas (restricted codes). Spektrum komunikasi internal dan eksternal partai yang tidak egaliter bukan hanya menjadikan klaim inklusivitas sebagai keterbukaan semu (quasi terbuka), tetapi juga mempertajam segregasi antarfaksi, sehingga partai menjadi mudah terfragmentasi ke dalam kekuatan sempalan.

Penguasaan sumber daya komunikasi partai politik yang terpusat di tangan figur melahirkan kepemimpinan partai yang mesianik. Pola ini bukan hanya melekatkan otoritas kepemimpinan pada tradisi dan kharisma sebagaimana lazim dianut selama ini, tetapi juga menempatkan figur sebagai mesiah (ratu adil) yang tidak pernah berbuat salah.
Kepemimpinan mesianik dikukuhkan oleh pola orientasi pengikut yang bercorak parokhial dan rekrutmen yang berdasar kepada nasab sehingga kelahiran dan perkawinan menjadi alat promosi karier yang penting. Sedemikian pentingnya peran politik keluarga-penguasa, maka perhatian para pencari kekuasaan tertuju pada pola kekuasaan keluarga sebagai miniatur pola kekuasaan partai. Partai sulit memainkan perannya sebagai representasi kepentingan pengikut, melainkan hanya mengukuhkan dominasi kaukus yang dibentuk tokoh-tokoh senior partai (gerontocracy). Kecenderungan ini mengukuhkan keberlakuan hukum besi oligarkhi, dimana aristokrat tradisional berperan sebagai oligoi-oligoi yang mengendalikan partai.

Pola komunikasi politik yang askriptif dan kepemimpinan mesianik menyebabkan tidak terbangunnya wacana kritis di kalangan fungsionaris dan simpatisan partai. Identifikasi kepartaian tidak terbangun atas penguasaan nilai dasar dan cita-cita partai, melainkan merupakan bentuk transformasi kesetiaan primordial ke dalam praksis politik. Involusi politik ini dikukuhkan oleh pola sosialisasi yang menempatkan kepatuhan di atas pertimbangan rasional. Manipulasi simbolsimbol agama dan budaya menjadi unsur primer dalam komunikasi antara pemimpin dengan pengikut sekaligus menjadi alat dominasi dan mobilisasi dukungan yang penting. Pola komunikasi tadi ditandai oleh pemakaian alat-alat retorika (baik verbal maupun nonverbal) yang bersumber dari - atau adaptasi bentuk ritual - agama dan budaya sehingga pemaknaan atas simbolsimbol tersebut bersifat isoterik sesuai dengan pengalaman religio-politik penggunanya.

Proses tersebut bukan hanya memberi peluang terjadinya kesalahpahaman, tetapi juga menguatkan kecenderungan menjadikan agama dan budaya sebagai alat justifikasi keputusan dan tindakan politik. Prinsip "ekonomi pernyataan" bukan hanya dapat mengurangi risiko keterpurukan citra akibat kesalahan manajemen komunikasi, tetapi juga dapat menambah daya persuasi komunikasi politik. 


\section{Daftar Pustaka}

Alwasilah, A. Chaedar. 2002. Pokoknya Kualitatif: Dasar-dasar Merancang dan Melakukan Penelitian Kualitatif. Jakarta: Pustaka Jaya.

Combs, James E \& Dan Nimmo 1981. A Primer of Politics. New York: Macmillan Publishing Company.

Creswell, John W. 1994. Research Design: Qualitative \& Quantitative Approaches. California: SAGE Publications.

1998. Qualitative Inquiry and Research Design: Choosing Among Five Traditions. California: SAGE Publications.

Feith, Herbert. 1962. The Decline of Constitutional Democracy in Indonesia. New York: Cornell University Press.

Feith, Herbert \& Lance Castles. 1970. Indonesian Political Thinking 1945-1965. USA: Cornell University.

Geertz, Clifford. 1981. Abangan, Santri, Priyayi dalam Masyarakat Jawa. Jakarta: Pustaka Jaya.

1992. Kebudayaan \& Agama, terjemahan Francisco Budi Hardiman. Yogyakarta: Kanisius.
1963. Old Societies and New States: The Quest for Modernity in Asia and Africa, The Free Press of Glencoe.

Goffman, Erving. 1974. The Presentation of Self ini Everyday Life. USA: Penguin Books.

Lewellen, Ted C. 1982. Political Anthropology, Berger L. Carey Publisher.

Martindale, Don. 1960. The Nature and Types of Sociological Theory, Cambridge, Massachusetts, The Riverside Press.

Mulyana, Deddy. 2001. Metode Penelitian Kualitatif: Paradigma Baru Ilmu Komunikasi dan Ilmu Sosial Lainnya. Bandung: Remaja Rosdakarya.

Nimmo, Dan D. dan Keith R. Sanders. 1981. Handbook of Political Communication. California: Sage Publication, Inc.

1978. Political Communication and Public Opinion in America. California: Goodyear Publishing Company.

Sherman, Arnolk K, dan Aliza Kolker. 1987. The Social Bases of Politics. Belmont: Wardworth Publishing Company, 


\title{
Transformasi Loyalitas Primordial sebagai Basis Identifikasi Kepartaian: Kasus Partai Kebangkitan Bangsa dalam Pemilihan Umum 1999 dan 2004
}

\author{
Karim Suryadi
}

ABSTRACT

\begin{abstract}
Transformation of primordial loyalty into the political sphere rather than understanding of the substance of the party's platform is a key factor for PKB's (National Awakening Party) devotees to adhere to the party. The platform has not been effectively socialized. The practice of the party has not been believed as a requisite condition to create an order society. On the other hand, adhering to Nahdlatul Ulama (NU) and inclining to submit to orders or wishes of Kiai (Muslim Scholars) is believed among PKB's voters as a means by which a good community is created (khoerul barriyah). Therefore, since the 2004 General Election,

Kiai's political communication and orientations have become the partisans' primary roles among $P K B$ 's constituents.
\end{abstract}

Kata kunci: "platform", identitas partai, komunikasi politik kiai, partisan, loyalitas primordial

\section{Pendahuluan}

Kemunculan Partai Kebangkitan Bangsa (PKB) dalam pusaran arus politik partai pasca Orde Baru menarik dikaji karena dua alasan berikut. Pertama, keterlibatan Pengurus Besar Nahdlatul Ulama (PBNU) dalam membidani kelahiran PKB mengisyaratkan keseriusannya dalam mengarahkan suara warga Nahdlatul Ulama (NU). Lebih dari sekadar merestui, keterlibatan PBNU dapat dibaca sebagai kesungguhan dalam melahirkan sang "putra mahkota". Padahal, aspirasi politik nahdliyin tidak benar-benar monolit. Partai politik yang lahir dari rahim NU bukan hanya PKB. Hal ini memunculkan dugaan adanya kesadaran yang mempersatukan dan mendesak warga NU untuk sementara - hanya akan berkhidmat pada PKB.
Kedua, dibanding partai baru lainnya, $\mathrm{PKB}$ adalah peraih suara terbanyak pada Pemilu 1999. Perolehan suara PKB mendekati raihan suara Partai NU pada Pemilu 1955. Jumlah ini melampaui raihan suara Partai Persatuan Pembangunan (PPP), yang sudah hadir sejak Orde Baru dan merupakan hasil fusi NU dengan Partai Muslimin Indonesia (Parmusi), Partai Syarikat Islam Indonesia (PSII), dan Persatuan Tarbiyah Indonesia (Perti), pada 5 Januari 1973.

Kembalinya NU ke kancah politik menarik dikaji, karena sejak 1984 NU memutuskan kembali ke khittah 1926. Keputusan ini bukan hanya mengharuskan NU menanggalkan atribut partai, tetapi juga menegaskan kembali jati dirinya sebagai organisasi sosial keagamaan (jam'iyyah diniyah). Fenomena ini memunculkan pertanyaan, faktor apa 
yang membuat dukungan terhadap PKB yang dianggap sebagai "titisan" Partai NU ini relatif stabil, padahal deideologisasi yang dijalankan Orde Baru berlangsung sangat intensif?

\section{Metode Penelitian}

Kemunculan PKB sebagai pemenang ketiga di bawah Partai Demokrasi Indonesia Perjuangan (PDIP) dan Partai Golongan Karya (Golkar), atau terbesar dibandingkan seluruh partai yang muncul pasca-Orde Baru, mengisyaratkan adanya gejala "reinkarnasi" politik NU yang tidak sempurna. Dugaan ini muncul karena kelahiran PKB dibidani NU, sehingga PKB menjadi anak emas NU. Namun, perolehan suara PKB yang jauh di bawah jumlah pemilih yang diasumsikan berhaluan NU menyiratkan dukungan warga NU terhadap PKB tidak bulat.

Selain menguatnya isu primordial, kemunculan partai politik menjelang Pemilu 1999 ditandai absennya platform yang dapat menggugah partisipasi publik. Fenomena ini memunculkan dugaan bahwa keputusan yang diambil pemilih saat memberikan suara dan loyalitas yang terbangun di kalangan para anggota lebih didasarkan atas pertimbangan di luar pemahaman mereka tentang platform partai.

Penelitian ini menggunakan metode studi kasus sebagai salah satu tradisi kualitatif(Creswell, 1998: 63) dengan pendekatan proses (Combs, 1981: 39-66). Proses sosialisasi platform pluralitas Partai Kebangkitan Bangsa (PKB) dan komunikasi politik kiai dalam membentuk identifikasi kepartaian dijadikan kasus dalam penelitian ini.

Data primer dalam penelitian ini dikumpulkan melalui wawancara terhadap 16 informan kunci dan beberapa kelompok informan yang digali dalam bentuk diskusi (focus group discussion). Untuk menghindari "bias partai", informasi dikumpulkan pula dari politisi NU yang berkiprah di luar PKB, seperti di PPP, Golkar, Partai Bintang Reformasi, dan PAN.

Informan ditentukan secara snowball, sehingga lokasi penelitian bergantung kepada di mana informan berada atau peristiwa politik yang digelar PKB berlangsung. Bandung, Jakarta, Cirebon, Sukabumi, Sampang, Pasuruan, dan Surabaya, sebagai daerah yang dikenal sebagai basis PKB menjadi daerah penelitian yang utama, serta Nusa Tenggara Timur (NTT), sebagai daerah percontohan pengembangan wawasan kebangsaan ala PKB.

Selain digali melalui wawancara mendalam, data primer dihimpun melalui pengamatan terlibat terhadap sejumlah objek dan peristiwa. Untuk kepentingan penelitian ini, telah dilakukan pengamatan dan wawancara dengan para pelaku yang terlibat dalam perumusan calon anggota legislatif dan kampanye menjelang Pemilu 2004. Berbagai forum yang bertujuan mematangkan calon presiden yang akan dimajukan PKB dan kampanye pemilihan presiden menjadi peristiwa yang penting.

Sementara, data sekunder dihimpun dari informasi kepustakaan, baik dari buku teks, jurnal ilmiah, hasil penelitian, laporan, dan dokumen; baik yang diterbitkan untuk umum maupun dokumen yang diterbitkan untuk kalangan internal PKB. Keseluruhan hasil penelitian kepustakaan menjadi sumber data yang penting bagi penelusuran polapola partisipasi dan komunikasi politik NU. Penelusuran data dokumenter difokuskan kepada keterlibatan ulama/kiai dalam wilayah politik serta akar-akar tradisi yang menjadi rujukan penyusunan platform.

Keseluruhan data dihimpun mulai September 2003 hingga Juni 2005. Data final yang dianalisis dan disajikan adalah data yang telah diseleksi melalui member checking.

\section{Genesis "Platform" dan Filogeni Politik PKB}

Bila dilihat dari kulturnya, PKB bukan entitas yang benar-benar baru. PKB hanya mewadahi sesuatu yang sudah ada, yakni komunitas NU dengan segenap sistem nilai yang dianutnya. Meskipun tidak terdapat hubungan organisatoris antara NU dan PKB, namun di antara keduanya sulit dipisahkan. PKB memang bukan organisasi yang dibentuk dengan tugas melaksanakan pro- 
gram-program NU, namun secara embrional PKB dan NU dihubungkan oleh "plasenta" yang sulit diputus.

Keterlibatan PBNU dalam membidani kelahiran PKB sampai pada derajat dituduh melanggar Khittah 1926, mengimplikasikan hal-hal berikut. Pertama, hasrat politik NU tidak padam karena langkah penarikan diri dari wilayah politik praktis. Hasrat berpolitik warga nahdliyin pun tidak tergerus deideologisasi yang diterapkan rezim Orde Baru. Bahkan langkah ini terbukti menjadi titik tolak ploriferasi politik NU.

Kedua, keputusan NU memfasilitasi pembentukan PKB merupakan bentuk adaptabilitas sikap politik NU. Fleksibilitas sikap politik NU terlihat di sepanjang sejarah pertumbuhan NU. Baik sebagai organisasi kemasyarakatan (jam'iyyah diniyah) maupun sebagai partai politik, sikap politik NU terkenal lentur. Meskipun dalam kasus tertentu NU tampil radikal (seperti menolak Perjanjian "Linggarjati" dan "Renville" atau ketika menolak Mutual Secutity Act dan dewan keamanan bersama yang pro AS pada 1952), namun watak akomodatif lebih mewarnai sikap politik NU.

Keterbukaan yang digagas para pendiri PKB dilandasi pandangan bahwa corak partai politik masa depan adalah lintas etnis, jauh melampaui keanggotaan sebuah organisasi kemasyarakatan. Pandangan ini menempatkan Pancasila sebagai asas partai, sekaligus menempatkan Islam sebagai akhlak masyarakat (etika sosial), dan sumber materi perundangan.

Beberapa dasar pertimbangan menyangkut pemilihan nama partai mengisyaratkan bahwa secara kultur PKB mengadopsi sikap kemasyarakatan yang dikembangkan NU. Kultur PKB adalah kultur NU, karena PKB adalah pengorganisasian kultur NU secara politik. Kultur Islam ahlussunnah wal Jama'ah menjadi basis historis dan ideologis PKB, yang bersenyawa dengan sejarah perjalanan kebangsaan dan kenegaraan Indonesia.

Namun, tidak semua warga NU memiliki pandangan yang sejalan dengan para pendiri PKB. Beberapa ulama mengritik karakter PKB yang terlalu berorientasi kebangsaan dan tidak secara tegas meneruskan tradisi politik Partai NU. Hal ini mengisyaratkan bahwa sikap politik warga NU tidak monolit. Mereka memiliki pemahaman yang beragam tentang bagaimana seharusnya tradisi politik NU ditransformasikan ke dalam praksis politik masa kini. Keragaman tadi telah mendorong munculnya beragam partai yang memiliki sejarah kekerabatan dengan NU (filogeni).

Filogeni politik PKB tidak didorong oleh perbedaan ideologis di antara empat partai yang lahir di kalangan NU. Perbedaan tadi hanya memperlihatkan "jalan yang berbeda menuju tujuan yang sama". Selain karena friksi yang terjadi di kalangan elit NU, kemunculan partai tersebut lebih disebabkan perbedaan penafsiran tentang bagaimana seharusnya sistem nilai yang dianut NU ditransformasikan ke dalam wilayah politik. Perbedaan tadi melemahkan barisan politik NU. Kekuatan NU terpecah ke dalam sekutu-sekutu kecil yang mudah digilas kekuatan lain.

Mabda Siyasiy memberikan gambaran jelas tentang hakikat PKB dan garis perjuangannya. Ideologi humanisme religius bukan hanya berakar pada fitrah manusia, tetapi juga mempertimbangkan taraf perkembangan manusia dalam konteks sosial. Paradigma humanisme berakar pada hakikat manusia yang suci, cenderung pada hal-hal yang baik, keunggulan indrawi dan memiliki akal. Sedangkan dimensi religius berkaitan dengan hidayah wahyu, pertolongan, dan petunjuk Allah swt. Artinya, selain menerima nilai-nilai yang diturunkan Allah swt, PKB pun menyerap nilainilai yang tumbuh dari perkembangan manusia.

Mengacu kepada sistem nilai yang terkandung di dalam Mabda Siyasiy jelas bahwa partai yang dikehendaki adalah partai yang terbuka. Meski naskah ini dirumuskan para tokoh NU, namun PKB tidak dimaksudkan sebagai reinkarnasi Partai NU. Berbeda dengan Partai NU yang pada awalnya mencita-citakan terwujudnya syari'at Islam dalam tatanan kenegaraan, PKB tidak mengusung formalisme Islam. Bagi PKB, mengambil sari pati nilai-nilai Islam untuk diangkat ke dalam hukum positiflebih diutamakan daripada menjadikan syari'at Islam sebagai dasar negara.

Kiai menjadi simbol signifikan dalam 
komunikasi politik PKB. Di antara para kiai, Abdurrahman Wahid masih menjadi primus inter pares. Figuritas Gus Dur bukan hanya dibentuk oleh keunggulan dari segi nasab, tetapi juga didukung oleh keluasan pengetahuan, paham pluralitasnya, dan sensitivitas terhadap budaya lokal. Pemerintahan Wahid yang hanya 21 bulan menjadi eksperimen implementasi platform pluralitas PKB.

Demokrasi dan penguatan masyarakat sipil (civil society) menjadi kredo (paham) pemerintahan Abdurrahman Wahid. Hal ini terlihat dari wacana dan langkah-langkah politik yang diambil Abdurrahman Wahid dalam 21 bulan kepemimpinannya.

Ide membangun kemandirian masyarakat sehingga tidak bergantung sepenuhnya kepada negara (otonomi relatif warga negara) menjadi gagasan besar Abdurrahman Wahid. Gagasan tadi diterjemahkan ke dalam wacana (kesatuan tutur) supremasi sipil, kemerdekaan pers dan kebebasan berbicara, pembelaan hak minoritas, penguatan posisi masyarakat di hadapan negara, supremasi hukum, dan deformalisasi Islam.

Selain mengembangkan wacana di atas, Abdurrahman Wahid pun melakukan "ijtihad" dalam hal hubungan penguasa dan rakyatnya. Kepala negara yang sebelumnya "sulit disentuh", dicitrakan sebagai terbuka dan dekat dengan rakyat. Hal ini paling tidak terlihat dari tindakannya melakukan desakralisasi istana dan memajukan informalitas komunikasi politik.

\section{Identifikasi Kepartaian}

Terlepas dari perolehan suara PKB yang masih kecil, langkah-langkah yang ditempuh kader PKB NTT memperlihatkan fenomena menarik. Fenomena tadi dalam beberapa hal mirip langkahlangkah yang ditempuh pengurus PKB di Jawa dengan spektrum yang berbeda.

Pertama, seperti halnya di Jawa, di NTT figur Gus Dur menjadi faktor penentu. Bukan platform yang memikat mereka. Figur Gus Dur yang dinilai mampu memberi keteduhan bagi warga Kristiani menawan mereka.
Kedua, seperti halnya di Jawa, identifikasi kepartaian belum terbentuk. Pemanfaatan struktur keagamaan Kristen sebagai strategi perluasan dukungan mendekati pola rekrutmen di Jawa yang memanfaatkan jaringan pesantren. Dengan kata lain, baik di Jawa maupun di NTT yang terjadi adalah transformasi kesetian primordial ke wilayah politik.

Ketiga, pemanfaatan pranata budaya sebagai media komunikasi politik. Ke dalamnya termasuk melakukan politik kultural dengan memanfaatkan opinion leaders, baik dalam wilayah adat maupun agama. Hal ini dimungkinkan karena masyarakat NTT terstruktur secara hierarkhis dengan raja dan kepala suku sebagai patronnya. Realitas terakhir, lagi-lagi, memiliki kemiripan dengan struktur masyarakat Jawa yang sentris, meski yang menjadi patron bukan kepala suku.

Keempat, selain menarik simpati masyarakat yang terlanjur jatuh hati pada Partai Golkar dan PDIP (orientasi merah-kuning) tantangan yang dihadapi kader PKB NTT adalah pencitraan. Citra PKB sebagai partai Islam melekat cukup kuat di benak masyarakat NTT. Citra seperti ini tidak menunjang pemasaran politik PKB. Karena itu, langkah yang ditempuh adalah mengarusutamakan citra PKB sebagai partai terbuka, nasionalis, dan demokratis. Namun dalam praktiknya, strategi tadi berbentuk deislamisasi, yakni mengurangi simbolsimbol keislaman.

Fenomena terakhir, berbeda kontras dengan realitas PKB di Jawa, khususnya Tapal Kuda. Namun, keduanya menemukan titik temu, yakni isu agama dan primordial menjadi "kartu" yang menentukan. Inilah dilema PKB dalam membangun demokrasi. Membangun demokrasi tidak bisa berlandaskan primordialisme, sebab nalar demokrasi menuntut egalitarianisme, transparansi, dan tanpa diskriminasi dalam semua bidang.

\section{Pola Komunikasi Politik Kiai}

Meskipun PKB bersifat terbuka dan dihuni oleh orang-orang dengan latar belakang budaya yang beragam, namun kultur NU tetap dominan. Dalam berbagai acara yang digelar PKB, baik di 
pusat maupun di daerah, kultur dan simbol NU masih menjadi mainstream (arus utama). Pembacaan shalawat dalam acara-acara yang digelar PKB adalah indikasi penetrasi kultur NU terhadap budaya komunikasi PKB.

Budaya NU menjadi rujukan reproduksi simbol-simbol PKB. Simbol-simbol PKB adalah modifikasi simbol-simbol NU yang ditransformasikan ke dalam lingkungan yang lebih luas. Proses transformatif tadi dapat dilukiskan dalam gambar berikut.

Kiai menjadi nucleus (unsur inti) komunitas pesantren dan NU. Pada gilirannya, ketiga unsur ini menjadi sumber dan rujukan dalam proses reproduksi simbol-simbol PKB. Dengan kata lain, simbol PKB adalah simbol-simbol NU yang telah mengalami metamorfosis. Di dalam proses ini, kiai yang berorientasi politik (political-oriented kiai) menjadi agen yang mempersambungkan prosesproses transformatif tadi.

Introduksi cara-cara modern (modernisasi) yang melanda warga NU - seperti yang ditandai oleh kahadiran struktur modern - belum mengubah pola-pola relasi yang sudah ada. Bahkan, ikatan terhadap faktor-faktor primordial menguat sejalan dengan pelekatan diri mereka terhadap struktur formal yang mereka ciptakan. Fenomena inilah yang menimbulkan kecenderungan munculnya etnisitas dalam politik (political ethnicity).

Modernisasi yang dijalani PKB tidak ditempuh dengan cara mengikis pola hubungan yang sudah ada, melainkan hanya memfungsikan kembali struktur-struktur tradisional yang sudah diwarisi. Faktor nasab, etnis, dan usia, masih menjadi unsur primer dalam alokasi kekuasaan. Diferensiasi antara wilayah politik dan religius hampir tidak terjadi. Hal ini dimungkinkan karena teologi sosial politik yang dianut amat fleksibel dalam menghadapi perubahan-perubahan yang muncul akibat politik modernisasi yang ditempuh PKB.

Sebagai pengorganisasian kultur NU secara politik, PKB mewarisi kerangka berpikir khas NU, yang tidak lain adalah organisasi sosial keagamaan (jam'iyyah ijtima'iyyah diniyyah). Kerangka berpikir tadi tampak dalam ciri-ciri primer NUdan dalam kiprah politiknya. Ciri-ciri primer tadi ditransformasikan ke dalam praksis politik PKB sehingga menjadi basis identifikasi kepartaian, terutama di daerah-daerah yang dikenal basis NU. Namun, sebagai partai politik yang dimaksudkan sebagai alat transformasi sosial politik NU, PKB dituntut memiliki sensitivitas terhadap nilai sosial politik yang relevan dengan kaidah-kaidah yang dianut NU.

Secara normatif, kerangka berpikir tadi ditemukan di dalam dokumen-dokumen historis PKB, tempat di mana ideologi politik PKB dituangkan. Preferensi tentang masyarakat dan negara yang dicita-citakan PKB bukan hanya berbasis pada etika dan nilai-nilai keagamaan, tetapi juga tidak sekuler - dalam arti memisahkan kehidupan bernegara dari kehidupan beragama meski sejak awal PKB tidak menghendaki formalisasi Islam.

Dilihat dari konteks di atas, sifat terbuka yang dianut PKB berkonotasi sebagai quasi terbuka, atau dalam bahasa para kiai di Jawa Timur sebagai "terbuka yang tertutup". Keterbukaan PKB berlaku sampai pada titik tidak mengganggu sistem nilai yang dianut NU. Sederhananya, PKB bersifat tertutup terhadap anasir-anasir yang merusak kaidah dasar yang dianut warga NU.

Dengan kata lain, quasi terbuka bermakna PKB itu inklusif sekaligus ekslusif. Inklusif dalam hal muamalah dan interaksi sosial, tetapi eksklusif dalam hal ibadah dan akidah. Kaidah ini bermakna bahwa PKB dapat menggelar kegiatan muamalah dan interaksi sosial tanpa membedakan agama dan latar belakang sosial budaya. Namun, PKB harus membatasi diri pada hal-hal yang menyangkut ibadah dan akidah.

Dalam hubungannya dengan anasir-anasir agama yang membentuk konfigurasi dukungan bagi PKB, keterbukaan harus dipahami sebagai sikap toleran (tasamuh) terhadap agama mana pun tanpa meninggalkan keyakinan teologisnya sendiri. Di dalam wilayah ibadah dan akidah, PKB tidak memiliki otoritas untuk ikut campur, meski tidak akan pernah terlepas sama sekali.

Karena itu, platform pluralitas PKB menuntut manajemen komunikasi tersendiri dalam proses 
sosialisasinya mengingat fakta bahwa PKB telah secara nyata membuka basis dukungan di kalangan non NU, bahkan non-Islam. Manajemen komunikasi PKB perlu dirancang paling tidak untuk dua kebutuhan.

Pertama, memelihara dukungan pemilih dari kalangan Muslim yang menjadi captive market, sekaligus menarik dukungan non-Muslim lewat penampilan sosok partai yang moderat. Sebelum menarik kelompok kedua, PKB harus mempertahankan dukungan kelompok pertama dengan meyakinkan bahwa format "Islam Kebangsaan" yang dianut NU dan diwarisi PKB adalah salah satu bentuk jawaban dalam mengatasi berbagai persoalan, khususnya dalam masalah relasi agama dan negara.

Sosok partai yang moderat menjadi daya tarik PKB di kalangan non-Muslim, paling tidak di Nusa Tenggara Timur. Beberapa pemilih PKB di kota Kupang mengaku tertarik pada PKB karena mampu memberi kesejukan bagi warga Kristiani, yang dalam kehidupan nasional menjadi minoritas. Sayangnya, eksperimen PKB menarik dukungan non-Muslim tidak dapat meningkatkan raihan suara PKB secara signifikan dalam Pemilu 2004. Bahkan, secara nasional raihan suara PKB menurun bila dibandingkan Pemilu 1999.

Kedua, menggeser kekuatan PKB dari anasiranasir yang bersifat primordial ke arah keunggulan kompetitifyang berlandaskan kultur, program, dan kepemimpinan. Namun, transformasi nilai tadi tidak bisa dilakukan secepat membalikkan telapak tangan karena ia menyangkut atribut sosial yang telah terlanjur dianggap sebagai pandangan hidup (ways of life).

Dikaji dari perspektif tadi, sosialisasi platform pluralitas PKB bertolak dari keyakinan bahwa akidah dan ritus ibadah setiap agama adalah hak ekslusif setiap pemeluknya. Wilayah ini merupakan area privat, yang tidak menjadi otoritas PKB untuk merekayasanya. Sosialisasi platform pluralitas PKB tidak menjangkau wilayah akidah dan ibadah, meskipun senantiasa mendapatkan penetrasi, bahkan dengan sengaja menyerap, nilai agama yang ditransformasikan ke dalam gelanggang politik.
Dengan demikian, medan khidmat sosialisasi platform pluralitas PKB adalah wilayah muamalah dan interaksi sosial, yakni seperangkat panduan sosial yang diturunkan dari nilai-nilai keagamaan dan berlaku universal. Mengacu kepada rumusan platform $\mathrm{PKB}$, nilai-nilai dasar dimaksud mencakup beberapa hal. Kesatu, jaminan penegakan HAM dan kejujuran besumber hati nurani (as-shidqu). Kedua, mengembangkan sikap dapat dipercaya, setia dan tepat janji. Ketiga, menciptakan tatanan masyarakat yang mampu memecahkan masalah sosial (al-amanah wa al-wafau bi al-ahdli), adil (al-'adalah), tolong-menolong (al-ta'awun), konsisten (al-istiqamah), musyawarah (al-syura), dan kesamaan kedudukan di muka hukum (almusawa).

Fakta bahwa tidak semua orang yang mengidentifikasikan dirinya dengan NU memilih PKB menunjukkan bahwa keputusan untuk memilih tidak semata-mata ditentukan oleh kekuatankekuatan dari luar. Demikian pula fakta bahwa sejumlah non-Muslim yang memutuskan memilih PKB menunjukkan bahwa tindakan politik mereka tidak tunduk pada pencitraan yang mengesankan PKB sebagai partai orang Islam. Kedua fakta ini mengisyaratkan bahwa tindakan politik warga PKB melibatkan proses interpretatif atas simbol-simbol yang dipertukarkan ketika proses komunikasi politik berlangsung.

Dikaji dari perspektif interaksi simbolik, sosialisasi platform pluralitas PKB akan bergantung kepada kualitas hubungan dan kelangsungan interaksi, di mana kedua pihak (aktivis, politisi, dan komunikator profesional versus khalayak, simpatisan, dan konstituen PKB) saling menukar makna dan kelakuan. Sebuah transaksi politik yang di dalamnya melibatkan proses penciptaan kesan melalui proses impression management (Goffman, 1959: 203).

Penataan kesan menjadi kunci keberhasilan politisi dalam serangkaian proses transasksi politik, karena sejak lama diyakini bahwa banyak aspek politik berupa penampilan (appearance). Para politikus beraksi di depan publik sedemikian rupa, sehingga mereka menganggapnya sebagai orang penting, pintar, dan layak dipercaya untuk 
mengemban amanah. Para pemimpin dan aktivis partai politik harus memainkan peran seperti yang dibayangkan khalayak. Mereka akan selalu menemukan banyak orang yang siap "dikelabui". Mereka menjanjikan sesuatu, sehingga mereka dikesani sebagai sosok yang merasakan sesuatu serta berpikir dan bertindak menurut apa yang dibayangkan konstituennya.

\section{Kesimpulan}

Pertumbuhan politik kepartaian di Indonesia tidak identik dengan sekularisasi, melainkan transformasi kesadaran religius ke dalam wilayah politik. Keyakinan bahwa urusan politik dapat diatur dan ditentukan oleh kehendak manusia sendiri tidak menafikan hak prerogatif Tuhan dalam keseluruhan proses tersebut.

Komunikasi internal dan esksternal yang tidak efektif menyebabkan substansi platform tidak tersosialisasikan dengan baik. Akibatnya keberadaan platform menjadi tidak fungsional. Platform menjadi atribut yang menunjang penampilan politisi dalam panggung depan. Kedudukan platform tergantikan oleh figur yang menjadi ikon (icon) sekaligus ruh partai. Kondisi ini melahirkan pola komunikasi politik yang melekatkan kredibilitas komunikator pada faktor-faktor yang diwariskan (askriptif) dan menempatkan figur sebagai mesiah. Pola ini mengukuhkan budaya konteks tinggi (high contex) yang ditandai oleh penggunaan kode terbatas (restricted codes). Spektrum komunikasi internal dan eksternal partai yang tidak egaliter bukan hanya menjadikan klaim inklusivitas sebagai keterbukaan semu (quasi terbuka), tetapi juga mempertajam segregasi antarfaksi, sehingga partai menjadi mudah terfragmentasi ke dalam kekuatan sempalan.

Penguasaan sumber daya komunikasi partai politik yang terpusat di tangan figur melahirkan kepemimpinan partai yang mesianik. Pola ini bukan hanya melekatkan otoritas kepemimpinan pada tradisi dan kharisma sebagaimana lazim dianut selama ini, tetapi juga menempatkan figur sebagai mesiah (ratu adil) yang tidak pernah berbuat salah.
Kepemimpinan mesianik dikukuhkan oleh pola orientasi pengikut yang bercorak parokhial dan rekrutmen yang berdasar kepada nasab sehingga kelahiran dan perkawinan menjadi alat promosi karier yang penting. Sedemikian pentingnya peran politik keluarga-penguasa, maka perhatian para pencari kekuasaan tertuju pada pola kekuasaan keluarga sebagai miniatur pola kekuasaan partai. Partai sulit memainkan perannya sebagai representasi kepentingan pengikut, melainkan hanya mengukuhkan dominasi kaukus yang dibentuk tokoh-tokoh senior partai (gerontocracy). Kecenderungan ini mengukuhkan keberlakuan hukum besi oligarkhi, dimana aristokrat tradisional berperan sebagai oligoi-oligoi yang mengendalikan partai.

Pola komunikasi politik yang askriptif dan kepemimpinan mesianik menyebabkan tidak terbangunnya wacana kritis di kalangan fungsionaris dan simpatisan partai. Identifikasi kepartaian tidak terbangun atas penguasaan nilai dasar dan cita-cita partai, melainkan merupakan bentuk transformasi kesetiaan primordial ke dalam praksis politik. Involusi politik ini dikukuhkan oleh pola sosialisasi yang menempatkan kepatuhan di atas pertimbangan rasional. Manipulasi simbolsimbol agama dan budaya menjadi unsur primer dalam komunikasi antara pemimpin dengan pengikut sekaligus menjadi alat dominasi dan mobilisasi dukungan yang penting. Pola komunikasi tadi ditandai oleh pemakaian alat-alat retorika (baik verbal maupun nonverbal) yang bersumber dari - atau adaptasi bentuk ritual - agama dan budaya sehingga pemaknaan atas simbolsimbol tersebut bersifat isoterik sesuai dengan pengalaman religio-politik penggunanya.

Proses tersebut bukan hanya memberi peluang terjadinya kesalahpahaman, tetapi juga menguatkan kecenderungan menjadikan agama dan budaya sebagai alat justifikasi keputusan dan tindakan politik. Prinsip "ekonomi pernyataan" bukan hanya dapat mengurangi risiko keterpurukan citra akibat kesalahan manajemen komunikasi, tetapi juga dapat menambah daya persuasi komunikasi politik. 


\section{Daftar Pustaka}

Alwasilah, A. Chaedar. 2002. Pokoknya Kualitatif: Dasar-dasar Merancang dan Melakukan Penelitian Kualitatif. Jakarta: Pustaka Jaya.

Combs, James E \& Dan Nimmo 1981. A Primer of Politics. New York: Macmillan Publishing Company.

Creswell, John W. 1994. Research Design: Qualitative \& Quantitative Approaches. California: SAGE Publications.

1998. Qualitative Inquiry and Research Design: Choosing Among Five Traditions. California: SAGE Publications.

Feith, Herbert. 1962. The Decline of Constitutional Democracy in Indonesia. New York: Cornell University Press.

Feith, Herbert \& Lance Castles. 1970. Indonesian Political Thinking 1945-1965. USA: Cornell University.

Geertz, Clifford. 1981. Abangan, Santri, Priyayi dalam Masyarakat Jawa. Jakarta: Pustaka Jaya.

1992. Kebudayaan \& Agama, terjemahan Francisco Budi Hardiman. Yogyakarta: Kanisius.
1963. Old Societies and New States: The Quest for Modernity in Asia and Africa, The Free Press of Glencoe.

Goffman, Erving. 1974. The Presentation of Self ini Everyday Life. USA: Penguin Books.

Lewellen, Ted C. 1982. Political Anthropology, Berger L. Carey Publisher.

Martindale, Don. 1960. The Nature and Types of Sociological Theory, Cambridge, Massachusetts, The Riverside Press.

Mulyana, Deddy. 2001. Metode Penelitian Kualitatif: Paradigma Baru Ilmu Komunikasi dan Ilmu Sosial Lainnya. Bandung: Remaja Rosdakarya.

Nimmo, Dan D. dan Keith R. Sanders. 1981. Handbook of Political Communication. California: Sage Publication, Inc.

1978. Political Communication and Public Opinion in America. California: Goodyear Publishing Company.

Sherman, Arnolk K, dan Aliza Kolker. 1987. The Social Bases of Politics. Belmont: Wardworth Publishing Company, 


\title{
Transformasi Loyalitas Primordial sebagai Basis Identifikasi Kepartaian: Kasus Partai Kebangkitan Bangsa dalam Pemilihan Umum 1999 dan 2004
}

\author{
Karim Suryadi
}

ABSTRACT

\begin{abstract}
Transformation of primordial loyalty into the political sphere rather than understanding of the substance of the party's platform is a key factor for PKB's (National Awakening Party) devotees to adhere to the party. The platform has not been effectively socialized. The practice of the party has not been believed as a requisite condition to create an order society. On the other hand, adhering to Nahdlatul Ulama (NU) and inclining to submit to orders or wishes of Kiai (Muslim Scholars) is believed among PKB's voters as a means by which a good community is created (khoerul barriyah). Therefore, since the 2004 General Election,

Kiai's political communication and orientations have become the partisans' primary roles among $P K B$ 's constituents.
\end{abstract}

Kata kunci: "platform", identitas partai, komunikasi politik kiai, partisan, loyalitas primordial

\section{Pendahuluan}

Kemunculan Partai Kebangkitan Bangsa (PKB) dalam pusaran arus politik partai pasca Orde Baru menarik dikaji karena dua alasan berikut. Pertama, keterlibatan Pengurus Besar Nahdlatul Ulama (PBNU) dalam membidani kelahiran PKB mengisyaratkan keseriusannya dalam mengarahkan suara warga Nahdlatul Ulama (NU). Lebih dari sekadar merestui, keterlibatan PBNU dapat dibaca sebagai kesungguhan dalam melahirkan sang "putra mahkota". Padahal, aspirasi politik nahdliyin tidak benar-benar monolit. Partai politik yang lahir dari rahim NU bukan hanya PKB. Hal ini memunculkan dugaan adanya kesadaran yang mempersatukan dan mendesak warga NU untuk sementara - hanya akan berkhidmat pada PKB.
Kedua, dibanding partai baru lainnya, $\mathrm{PKB}$ adalah peraih suara terbanyak pada Pemilu 1999. Perolehan suara PKB mendekati raihan suara Partai NU pada Pemilu 1955. Jumlah ini melampaui raihan suara Partai Persatuan Pembangunan (PPP), yang sudah hadir sejak Orde Baru dan merupakan hasil fusi NU dengan Partai Muslimin Indonesia (Parmusi), Partai Syarikat Islam Indonesia (PSII), dan Persatuan Tarbiyah Indonesia (Perti), pada 5 Januari 1973.

Kembalinya NU ke kancah politik menarik dikaji, karena sejak 1984 NU memutuskan kembali ke khittah 1926. Keputusan ini bukan hanya mengharuskan NU menanggalkan atribut partai, tetapi juga menegaskan kembali jati dirinya sebagai organisasi sosial keagamaan (jam'iyyah diniyah). Fenomena ini memunculkan pertanyaan, faktor apa 
yang membuat dukungan terhadap PKB yang dianggap sebagai "titisan" Partai NU ini relatif stabil, padahal deideologisasi yang dijalankan Orde Baru berlangsung sangat intensif?

\section{Metode Penelitian}

Kemunculan PKB sebagai pemenang ketiga di bawah Partai Demokrasi Indonesia Perjuangan (PDIP) dan Partai Golongan Karya (Golkar), atau terbesar dibandingkan seluruh partai yang muncul pasca-Orde Baru, mengisyaratkan adanya gejala "reinkarnasi" politik NU yang tidak sempurna. Dugaan ini muncul karena kelahiran PKB dibidani NU, sehingga PKB menjadi anak emas NU. Namun, perolehan suara PKB yang jauh di bawah jumlah pemilih yang diasumsikan berhaluan NU menyiratkan dukungan warga NU terhadap PKB tidak bulat.

Selain menguatnya isu primordial, kemunculan partai politik menjelang Pemilu 1999 ditandai absennya platform yang dapat menggugah partisipasi publik. Fenomena ini memunculkan dugaan bahwa keputusan yang diambil pemilih saat memberikan suara dan loyalitas yang terbangun di kalangan para anggota lebih didasarkan atas pertimbangan di luar pemahaman mereka tentang platform partai.

Penelitian ini menggunakan metode studi kasus sebagai salah satu tradisi kualitatif(Creswell, 1998: 63) dengan pendekatan proses (Combs, 1981: 39-66). Proses sosialisasi platform pluralitas Partai Kebangkitan Bangsa (PKB) dan komunikasi politik kiai dalam membentuk identifikasi kepartaian dijadikan kasus dalam penelitian ini.

Data primer dalam penelitian ini dikumpulkan melalui wawancara terhadap 16 informan kunci dan beberapa kelompok informan yang digali dalam bentuk diskusi (focus group discussion). Untuk menghindari "bias partai", informasi dikumpulkan pula dari politisi NU yang berkiprah di luar PKB, seperti di PPP, Golkar, Partai Bintang Reformasi, dan PAN.

Informan ditentukan secara snowball, sehingga lokasi penelitian bergantung kepada di mana informan berada atau peristiwa politik yang digelar PKB berlangsung. Bandung, Jakarta, Cirebon, Sukabumi, Sampang, Pasuruan, dan Surabaya, sebagai daerah yang dikenal sebagai basis PKB menjadi daerah penelitian yang utama, serta Nusa Tenggara Timur (NTT), sebagai daerah percontohan pengembangan wawasan kebangsaan ala PKB.

Selain digali melalui wawancara mendalam, data primer dihimpun melalui pengamatan terlibat terhadap sejumlah objek dan peristiwa. Untuk kepentingan penelitian ini, telah dilakukan pengamatan dan wawancara dengan para pelaku yang terlibat dalam perumusan calon anggota legislatif dan kampanye menjelang Pemilu 2004. Berbagai forum yang bertujuan mematangkan calon presiden yang akan dimajukan PKB dan kampanye pemilihan presiden menjadi peristiwa yang penting.

Sementara, data sekunder dihimpun dari informasi kepustakaan, baik dari buku teks, jurnal ilmiah, hasil penelitian, laporan, dan dokumen; baik yang diterbitkan untuk umum maupun dokumen yang diterbitkan untuk kalangan internal PKB. Keseluruhan hasil penelitian kepustakaan menjadi sumber data yang penting bagi penelusuran polapola partisipasi dan komunikasi politik NU. Penelusuran data dokumenter difokuskan kepada keterlibatan ulama/kiai dalam wilayah politik serta akar-akar tradisi yang menjadi rujukan penyusunan platform.

Keseluruhan data dihimpun mulai September 2003 hingga Juni 2005. Data final yang dianalisis dan disajikan adalah data yang telah diseleksi melalui member checking.

\section{Genesis "Platform" dan Filogeni Politik PKB}

Bila dilihat dari kulturnya, PKB bukan entitas yang benar-benar baru. PKB hanya mewadahi sesuatu yang sudah ada, yakni komunitas NU dengan segenap sistem nilai yang dianutnya. Meskipun tidak terdapat hubungan organisatoris antara NU dan PKB, namun di antara keduanya sulit dipisahkan. PKB memang bukan organisasi yang dibentuk dengan tugas melaksanakan pro- 
gram-program NU, namun secara embrional PKB dan NU dihubungkan oleh "plasenta" yang sulit diputus.

Keterlibatan PBNU dalam membidani kelahiran PKB sampai pada derajat dituduh melanggar Khittah 1926, mengimplikasikan hal-hal berikut. Pertama, hasrat politik NU tidak padam karena langkah penarikan diri dari wilayah politik praktis. Hasrat berpolitik warga nahdliyin pun tidak tergerus deideologisasi yang diterapkan rezim Orde Baru. Bahkan langkah ini terbukti menjadi titik tolak ploriferasi politik NU.

Kedua, keputusan NU memfasilitasi pembentukan PKB merupakan bentuk adaptabilitas sikap politik NU. Fleksibilitas sikap politik NU terlihat di sepanjang sejarah pertumbuhan NU. Baik sebagai organisasi kemasyarakatan (jam'iyyah diniyah) maupun sebagai partai politik, sikap politik NU terkenal lentur. Meskipun dalam kasus tertentu NU tampil radikal (seperti menolak Perjanjian "Linggarjati" dan "Renville" atau ketika menolak Mutual Secutity Act dan dewan keamanan bersama yang pro AS pada 1952), namun watak akomodatif lebih mewarnai sikap politik NU.

Keterbukaan yang digagas para pendiri PKB dilandasi pandangan bahwa corak partai politik masa depan adalah lintas etnis, jauh melampaui keanggotaan sebuah organisasi kemasyarakatan. Pandangan ini menempatkan Pancasila sebagai asas partai, sekaligus menempatkan Islam sebagai akhlak masyarakat (etika sosial), dan sumber materi perundangan.

Beberapa dasar pertimbangan menyangkut pemilihan nama partai mengisyaratkan bahwa secara kultur PKB mengadopsi sikap kemasyarakatan yang dikembangkan NU. Kultur PKB adalah kultur NU, karena PKB adalah pengorganisasian kultur NU secara politik. Kultur Islam ahlussunnah wal Jama'ah menjadi basis historis dan ideologis PKB, yang bersenyawa dengan sejarah perjalanan kebangsaan dan kenegaraan Indonesia.

Namun, tidak semua warga NU memiliki pandangan yang sejalan dengan para pendiri PKB. Beberapa ulama mengritik karakter PKB yang terlalu berorientasi kebangsaan dan tidak secara tegas meneruskan tradisi politik Partai NU. Hal ini mengisyaratkan bahwa sikap politik warga NU tidak monolit. Mereka memiliki pemahaman yang beragam tentang bagaimana seharusnya tradisi politik NU ditransformasikan ke dalam praksis politik masa kini. Keragaman tadi telah mendorong munculnya beragam partai yang memiliki sejarah kekerabatan dengan NU (filogeni).

Filogeni politik PKB tidak didorong oleh perbedaan ideologis di antara empat partai yang lahir di kalangan NU. Perbedaan tadi hanya memperlihatkan "jalan yang berbeda menuju tujuan yang sama". Selain karena friksi yang terjadi di kalangan elit NU, kemunculan partai tersebut lebih disebabkan perbedaan penafsiran tentang bagaimana seharusnya sistem nilai yang dianut NU ditransformasikan ke dalam wilayah politik. Perbedaan tadi melemahkan barisan politik NU. Kekuatan NU terpecah ke dalam sekutu-sekutu kecil yang mudah digilas kekuatan lain.

Mabda Siyasiy memberikan gambaran jelas tentang hakikat PKB dan garis perjuangannya. Ideologi humanisme religius bukan hanya berakar pada fitrah manusia, tetapi juga mempertimbangkan taraf perkembangan manusia dalam konteks sosial. Paradigma humanisme berakar pada hakikat manusia yang suci, cenderung pada hal-hal yang baik, keunggulan indrawi dan memiliki akal. Sedangkan dimensi religius berkaitan dengan hidayah wahyu, pertolongan, dan petunjuk Allah swt. Artinya, selain menerima nilai-nilai yang diturunkan Allah swt, PKB pun menyerap nilainilai yang tumbuh dari perkembangan manusia.

Mengacu kepada sistem nilai yang terkandung di dalam Mabda Siyasiy jelas bahwa partai yang dikehendaki adalah partai yang terbuka. Meski naskah ini dirumuskan para tokoh NU, namun PKB tidak dimaksudkan sebagai reinkarnasi Partai NU. Berbeda dengan Partai NU yang pada awalnya mencita-citakan terwujudnya syari'at Islam dalam tatanan kenegaraan, PKB tidak mengusung formalisme Islam. Bagi PKB, mengambil sari pati nilai-nilai Islam untuk diangkat ke dalam hukum positiflebih diutamakan daripada menjadikan syari'at Islam sebagai dasar negara.

Kiai menjadi simbol signifikan dalam 
komunikasi politik PKB. Di antara para kiai, Abdurrahman Wahid masih menjadi primus inter pares. Figuritas Gus Dur bukan hanya dibentuk oleh keunggulan dari segi nasab, tetapi juga didukung oleh keluasan pengetahuan, paham pluralitasnya, dan sensitivitas terhadap budaya lokal. Pemerintahan Wahid yang hanya 21 bulan menjadi eksperimen implementasi platform pluralitas PKB.

Demokrasi dan penguatan masyarakat sipil (civil society) menjadi kredo (paham) pemerintahan Abdurrahman Wahid. Hal ini terlihat dari wacana dan langkah-langkah politik yang diambil Abdurrahman Wahid dalam 21 bulan kepemimpinannya.

Ide membangun kemandirian masyarakat sehingga tidak bergantung sepenuhnya kepada negara (otonomi relatif warga negara) menjadi gagasan besar Abdurrahman Wahid. Gagasan tadi diterjemahkan ke dalam wacana (kesatuan tutur) supremasi sipil, kemerdekaan pers dan kebebasan berbicara, pembelaan hak minoritas, penguatan posisi masyarakat di hadapan negara, supremasi hukum, dan deformalisasi Islam.

Selain mengembangkan wacana di atas, Abdurrahman Wahid pun melakukan "ijtihad" dalam hal hubungan penguasa dan rakyatnya. Kepala negara yang sebelumnya "sulit disentuh", dicitrakan sebagai terbuka dan dekat dengan rakyat. Hal ini paling tidak terlihat dari tindakannya melakukan desakralisasi istana dan memajukan informalitas komunikasi politik.

\section{Identifikasi Kepartaian}

Terlepas dari perolehan suara PKB yang masih kecil, langkah-langkah yang ditempuh kader PKB NTT memperlihatkan fenomena menarik. Fenomena tadi dalam beberapa hal mirip langkahlangkah yang ditempuh pengurus PKB di Jawa dengan spektrum yang berbeda.

Pertama, seperti halnya di Jawa, di NTT figur Gus Dur menjadi faktor penentu. Bukan platform yang memikat mereka. Figur Gus Dur yang dinilai mampu memberi keteduhan bagi warga Kristiani menawan mereka.
Kedua, seperti halnya di Jawa, identifikasi kepartaian belum terbentuk. Pemanfaatan struktur keagamaan Kristen sebagai strategi perluasan dukungan mendekati pola rekrutmen di Jawa yang memanfaatkan jaringan pesantren. Dengan kata lain, baik di Jawa maupun di NTT yang terjadi adalah transformasi kesetian primordial ke wilayah politik.

Ketiga, pemanfaatan pranata budaya sebagai media komunikasi politik. Ke dalamnya termasuk melakukan politik kultural dengan memanfaatkan opinion leaders, baik dalam wilayah adat maupun agama. Hal ini dimungkinkan karena masyarakat NTT terstruktur secara hierarkhis dengan raja dan kepala suku sebagai patronnya. Realitas terakhir, lagi-lagi, memiliki kemiripan dengan struktur masyarakat Jawa yang sentris, meski yang menjadi patron bukan kepala suku.

Keempat, selain menarik simpati masyarakat yang terlanjur jatuh hati pada Partai Golkar dan PDIP (orientasi merah-kuning) tantangan yang dihadapi kader PKB NTT adalah pencitraan. Citra PKB sebagai partai Islam melekat cukup kuat di benak masyarakat NTT. Citra seperti ini tidak menunjang pemasaran politik PKB. Karena itu, langkah yang ditempuh adalah mengarusutamakan citra PKB sebagai partai terbuka, nasionalis, dan demokratis. Namun dalam praktiknya, strategi tadi berbentuk deislamisasi, yakni mengurangi simbolsimbol keislaman.

Fenomena terakhir, berbeda kontras dengan realitas PKB di Jawa, khususnya Tapal Kuda. Namun, keduanya menemukan titik temu, yakni isu agama dan primordial menjadi "kartu" yang menentukan. Inilah dilema PKB dalam membangun demokrasi. Membangun demokrasi tidak bisa berlandaskan primordialisme, sebab nalar demokrasi menuntut egalitarianisme, transparansi, dan tanpa diskriminasi dalam semua bidang.

\section{Pola Komunikasi Politik Kiai}

Meskipun PKB bersifat terbuka dan dihuni oleh orang-orang dengan latar belakang budaya yang beragam, namun kultur NU tetap dominan. Dalam berbagai acara yang digelar PKB, baik di 
pusat maupun di daerah, kultur dan simbol NU masih menjadi mainstream (arus utama). Pembacaan shalawat dalam acara-acara yang digelar PKB adalah indikasi penetrasi kultur NU terhadap budaya komunikasi PKB.

Budaya NU menjadi rujukan reproduksi simbol-simbol PKB. Simbol-simbol PKB adalah modifikasi simbol-simbol NU yang ditransformasikan ke dalam lingkungan yang lebih luas. Proses transformatif tadi dapat dilukiskan dalam gambar berikut.

Kiai menjadi nucleus (unsur inti) komunitas pesantren dan NU. Pada gilirannya, ketiga unsur ini menjadi sumber dan rujukan dalam proses reproduksi simbol-simbol PKB. Dengan kata lain, simbol PKB adalah simbol-simbol NU yang telah mengalami metamorfosis. Di dalam proses ini, kiai yang berorientasi politik (political-oriented kiai) menjadi agen yang mempersambungkan prosesproses transformatif tadi.

Introduksi cara-cara modern (modernisasi) yang melanda warga NU - seperti yang ditandai oleh kahadiran struktur modern - belum mengubah pola-pola relasi yang sudah ada. Bahkan, ikatan terhadap faktor-faktor primordial menguat sejalan dengan pelekatan diri mereka terhadap struktur formal yang mereka ciptakan. Fenomena inilah yang menimbulkan kecenderungan munculnya etnisitas dalam politik (political ethnicity).

Modernisasi yang dijalani PKB tidak ditempuh dengan cara mengikis pola hubungan yang sudah ada, melainkan hanya memfungsikan kembali struktur-struktur tradisional yang sudah diwarisi. Faktor nasab, etnis, dan usia, masih menjadi unsur primer dalam alokasi kekuasaan. Diferensiasi antara wilayah politik dan religius hampir tidak terjadi. Hal ini dimungkinkan karena teologi sosial politik yang dianut amat fleksibel dalam menghadapi perubahan-perubahan yang muncul akibat politik modernisasi yang ditempuh PKB.

Sebagai pengorganisasian kultur NU secara politik, PKB mewarisi kerangka berpikir khas NU, yang tidak lain adalah organisasi sosial keagamaan (jam'iyyah ijtima'iyyah diniyyah). Kerangka berpikir tadi tampak dalam ciri-ciri primer NUdan dalam kiprah politiknya. Ciri-ciri primer tadi ditransformasikan ke dalam praksis politik PKB sehingga menjadi basis identifikasi kepartaian, terutama di daerah-daerah yang dikenal basis NU. Namun, sebagai partai politik yang dimaksudkan sebagai alat transformasi sosial politik NU, PKB dituntut memiliki sensitivitas terhadap nilai sosial politik yang relevan dengan kaidah-kaidah yang dianut NU.

Secara normatif, kerangka berpikir tadi ditemukan di dalam dokumen-dokumen historis PKB, tempat di mana ideologi politik PKB dituangkan. Preferensi tentang masyarakat dan negara yang dicita-citakan PKB bukan hanya berbasis pada etika dan nilai-nilai keagamaan, tetapi juga tidak sekuler - dalam arti memisahkan kehidupan bernegara dari kehidupan beragama meski sejak awal PKB tidak menghendaki formalisasi Islam.

Dilihat dari konteks di atas, sifat terbuka yang dianut PKB berkonotasi sebagai quasi terbuka, atau dalam bahasa para kiai di Jawa Timur sebagai "terbuka yang tertutup". Keterbukaan PKB berlaku sampai pada titik tidak mengganggu sistem nilai yang dianut NU. Sederhananya, PKB bersifat tertutup terhadap anasir-anasir yang merusak kaidah dasar yang dianut warga NU.

Dengan kata lain, quasi terbuka bermakna PKB itu inklusif sekaligus ekslusif. Inklusif dalam hal muamalah dan interaksi sosial, tetapi eksklusif dalam hal ibadah dan akidah. Kaidah ini bermakna bahwa PKB dapat menggelar kegiatan muamalah dan interaksi sosial tanpa membedakan agama dan latar belakang sosial budaya. Namun, PKB harus membatasi diri pada hal-hal yang menyangkut ibadah dan akidah.

Dalam hubungannya dengan anasir-anasir agama yang membentuk konfigurasi dukungan bagi PKB, keterbukaan harus dipahami sebagai sikap toleran (tasamuh) terhadap agama mana pun tanpa meninggalkan keyakinan teologisnya sendiri. Di dalam wilayah ibadah dan akidah, PKB tidak memiliki otoritas untuk ikut campur, meski tidak akan pernah terlepas sama sekali.

Karena itu, platform pluralitas PKB menuntut manajemen komunikasi tersendiri dalam proses 
sosialisasinya mengingat fakta bahwa PKB telah secara nyata membuka basis dukungan di kalangan non NU, bahkan non-Islam. Manajemen komunikasi PKB perlu dirancang paling tidak untuk dua kebutuhan.

Pertama, memelihara dukungan pemilih dari kalangan Muslim yang menjadi captive market, sekaligus menarik dukungan non-Muslim lewat penampilan sosok partai yang moderat. Sebelum menarik kelompok kedua, PKB harus mempertahankan dukungan kelompok pertama dengan meyakinkan bahwa format "Islam Kebangsaan" yang dianut NU dan diwarisi PKB adalah salah satu bentuk jawaban dalam mengatasi berbagai persoalan, khususnya dalam masalah relasi agama dan negara.

Sosok partai yang moderat menjadi daya tarik PKB di kalangan non-Muslim, paling tidak di Nusa Tenggara Timur. Beberapa pemilih PKB di kota Kupang mengaku tertarik pada PKB karena mampu memberi kesejukan bagi warga Kristiani, yang dalam kehidupan nasional menjadi minoritas. Sayangnya, eksperimen PKB menarik dukungan non-Muslim tidak dapat meningkatkan raihan suara PKB secara signifikan dalam Pemilu 2004. Bahkan, secara nasional raihan suara PKB menurun bila dibandingkan Pemilu 1999.

Kedua, menggeser kekuatan PKB dari anasiranasir yang bersifat primordial ke arah keunggulan kompetitifyang berlandaskan kultur, program, dan kepemimpinan. Namun, transformasi nilai tadi tidak bisa dilakukan secepat membalikkan telapak tangan karena ia menyangkut atribut sosial yang telah terlanjur dianggap sebagai pandangan hidup (ways of life).

Dikaji dari perspektif tadi, sosialisasi platform pluralitas PKB bertolak dari keyakinan bahwa akidah dan ritus ibadah setiap agama adalah hak ekslusif setiap pemeluknya. Wilayah ini merupakan area privat, yang tidak menjadi otoritas PKB untuk merekayasanya. Sosialisasi platform pluralitas PKB tidak menjangkau wilayah akidah dan ibadah, meskipun senantiasa mendapatkan penetrasi, bahkan dengan sengaja menyerap, nilai agama yang ditransformasikan ke dalam gelanggang politik.
Dengan demikian, medan khidmat sosialisasi platform pluralitas PKB adalah wilayah muamalah dan interaksi sosial, yakni seperangkat panduan sosial yang diturunkan dari nilai-nilai keagamaan dan berlaku universal. Mengacu kepada rumusan platform $\mathrm{PKB}$, nilai-nilai dasar dimaksud mencakup beberapa hal. Kesatu, jaminan penegakan HAM dan kejujuran besumber hati nurani (as-shidqu). Kedua, mengembangkan sikap dapat dipercaya, setia dan tepat janji. Ketiga, menciptakan tatanan masyarakat yang mampu memecahkan masalah sosial (al-amanah wa al-wafau bi al-ahdli), adil (al-'adalah), tolong-menolong (al-ta'awun), konsisten (al-istiqamah), musyawarah (al-syura), dan kesamaan kedudukan di muka hukum (almusawa).

Fakta bahwa tidak semua orang yang mengidentifikasikan dirinya dengan NU memilih PKB menunjukkan bahwa keputusan untuk memilih tidak semata-mata ditentukan oleh kekuatankekuatan dari luar. Demikian pula fakta bahwa sejumlah non-Muslim yang memutuskan memilih PKB menunjukkan bahwa tindakan politik mereka tidak tunduk pada pencitraan yang mengesankan PKB sebagai partai orang Islam. Kedua fakta ini mengisyaratkan bahwa tindakan politik warga PKB melibatkan proses interpretatif atas simbol-simbol yang dipertukarkan ketika proses komunikasi politik berlangsung.

Dikaji dari perspektif interaksi simbolik, sosialisasi platform pluralitas PKB akan bergantung kepada kualitas hubungan dan kelangsungan interaksi, di mana kedua pihak (aktivis, politisi, dan komunikator profesional versus khalayak, simpatisan, dan konstituen PKB) saling menukar makna dan kelakuan. Sebuah transaksi politik yang di dalamnya melibatkan proses penciptaan kesan melalui proses impression management (Goffman, 1959: 203).

Penataan kesan menjadi kunci keberhasilan politisi dalam serangkaian proses transasksi politik, karena sejak lama diyakini bahwa banyak aspek politik berupa penampilan (appearance). Para politikus beraksi di depan publik sedemikian rupa, sehingga mereka menganggapnya sebagai orang penting, pintar, dan layak dipercaya untuk 
mengemban amanah. Para pemimpin dan aktivis partai politik harus memainkan peran seperti yang dibayangkan khalayak. Mereka akan selalu menemukan banyak orang yang siap "dikelabui". Mereka menjanjikan sesuatu, sehingga mereka dikesani sebagai sosok yang merasakan sesuatu serta berpikir dan bertindak menurut apa yang dibayangkan konstituennya.

\section{Kesimpulan}

Pertumbuhan politik kepartaian di Indonesia tidak identik dengan sekularisasi, melainkan transformasi kesadaran religius ke dalam wilayah politik. Keyakinan bahwa urusan politik dapat diatur dan ditentukan oleh kehendak manusia sendiri tidak menafikan hak prerogatif Tuhan dalam keseluruhan proses tersebut.

Komunikasi internal dan esksternal yang tidak efektif menyebabkan substansi platform tidak tersosialisasikan dengan baik. Akibatnya keberadaan platform menjadi tidak fungsional. Platform menjadi atribut yang menunjang penampilan politisi dalam panggung depan. Kedudukan platform tergantikan oleh figur yang menjadi ikon (icon) sekaligus ruh partai. Kondisi ini melahirkan pola komunikasi politik yang melekatkan kredibilitas komunikator pada faktor-faktor yang diwariskan (askriptif) dan menempatkan figur sebagai mesiah. Pola ini mengukuhkan budaya konteks tinggi (high contex) yang ditandai oleh penggunaan kode terbatas (restricted codes). Spektrum komunikasi internal dan eksternal partai yang tidak egaliter bukan hanya menjadikan klaim inklusivitas sebagai keterbukaan semu (quasi terbuka), tetapi juga mempertajam segregasi antarfaksi, sehingga partai menjadi mudah terfragmentasi ke dalam kekuatan sempalan.

Penguasaan sumber daya komunikasi partai politik yang terpusat di tangan figur melahirkan kepemimpinan partai yang mesianik. Pola ini bukan hanya melekatkan otoritas kepemimpinan pada tradisi dan kharisma sebagaimana lazim dianut selama ini, tetapi juga menempatkan figur sebagai mesiah (ratu adil) yang tidak pernah berbuat salah.
Kepemimpinan mesianik dikukuhkan oleh pola orientasi pengikut yang bercorak parokhial dan rekrutmen yang berdasar kepada nasab sehingga kelahiran dan perkawinan menjadi alat promosi karier yang penting. Sedemikian pentingnya peran politik keluarga-penguasa, maka perhatian para pencari kekuasaan tertuju pada pola kekuasaan keluarga sebagai miniatur pola kekuasaan partai. Partai sulit memainkan perannya sebagai representasi kepentingan pengikut, melainkan hanya mengukuhkan dominasi kaukus yang dibentuk tokoh-tokoh senior partai (gerontocracy). Kecenderungan ini mengukuhkan keberlakuan hukum besi oligarkhi, dimana aristokrat tradisional berperan sebagai oligoi-oligoi yang mengendalikan partai.

Pola komunikasi politik yang askriptif dan kepemimpinan mesianik menyebabkan tidak terbangunnya wacana kritis di kalangan fungsionaris dan simpatisan partai. Identifikasi kepartaian tidak terbangun atas penguasaan nilai dasar dan cita-cita partai, melainkan merupakan bentuk transformasi kesetiaan primordial ke dalam praksis politik. Involusi politik ini dikukuhkan oleh pola sosialisasi yang menempatkan kepatuhan di atas pertimbangan rasional. Manipulasi simbolsimbol agama dan budaya menjadi unsur primer dalam komunikasi antara pemimpin dengan pengikut sekaligus menjadi alat dominasi dan mobilisasi dukungan yang penting. Pola komunikasi tadi ditandai oleh pemakaian alat-alat retorika (baik verbal maupun nonverbal) yang bersumber dari - atau adaptasi bentuk ritual - agama dan budaya sehingga pemaknaan atas simbolsimbol tersebut bersifat isoterik sesuai dengan pengalaman religio-politik penggunanya.

Proses tersebut bukan hanya memberi peluang terjadinya kesalahpahaman, tetapi juga menguatkan kecenderungan menjadikan agama dan budaya sebagai alat justifikasi keputusan dan tindakan politik. Prinsip "ekonomi pernyataan" bukan hanya dapat mengurangi risiko keterpurukan citra akibat kesalahan manajemen komunikasi, tetapi juga dapat menambah daya persuasi komunikasi politik. 


\section{Daftar Pustaka}

Alwasilah, A. Chaedar. 2002. Pokoknya Kualitatif: Dasar-dasar Merancang dan Melakukan Penelitian Kualitatif. Jakarta: Pustaka Jaya.

Combs, James E \& Dan Nimmo 1981. A Primer of Politics. New York: Macmillan Publishing Company.

Creswell, John W. 1994. Research Design: Qualitative \& Quantitative Approaches. California: SAGE Publications.

1998. Qualitative Inquiry and Research Design: Choosing Among Five Traditions. California: SAGE Publications.

Feith, Herbert. 1962. The Decline of Constitutional Democracy in Indonesia. New York: Cornell University Press.

Feith, Herbert \& Lance Castles. 1970. Indonesian Political Thinking 1945-1965. USA: Cornell University.

Geertz, Clifford. 1981. Abangan, Santri, Priyayi dalam Masyarakat Jawa. Jakarta: Pustaka Jaya.

1992. Kebudayaan \& Agama, terjemahan Francisco Budi Hardiman. Yogyakarta: Kanisius.
1963. Old Societies and New States: The Quest for Modernity in Asia and Africa, The Free Press of Glencoe.

Goffman, Erving. 1974. The Presentation of Self ini Everyday Life. USA: Penguin Books.

Lewellen, Ted C. 1982. Political Anthropology, Berger L. Carey Publisher.

Martindale, Don. 1960. The Nature and Types of Sociological Theory, Cambridge, Massachusetts, The Riverside Press.

Mulyana, Deddy. 2001. Metode Penelitian Kualitatif: Paradigma Baru Ilmu Komunikasi dan Ilmu Sosial Lainnya. Bandung: Remaja Rosdakarya.

Nimmo, Dan D. dan Keith R. Sanders. 1981. Handbook of Political Communication. California: Sage Publication, Inc.

1978. Political Communication and Public Opinion in America. California: Goodyear Publishing Company.

Sherman, Arnolk K, dan Aliza Kolker. 1987. The Social Bases of Politics. Belmont: Wardworth Publishing Company, 